PNNL-11811

UC-721A

\title{
Energy Vulnerability Relationships
}

B.R. Shaw

J.L. Boesen

February 1998

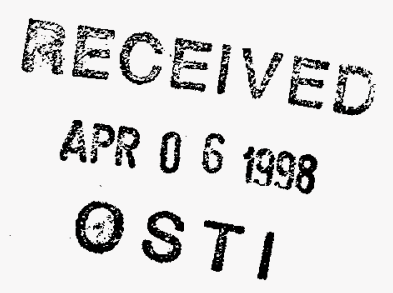

Prepared for the U.S. Department of Energy under Contract DE-AC06-76RLO 1830

DISTRIBUTION OF THIS DOCUMENT IS UNLIMITED 


\title{
DISCLAIMER
}

This report was prepared as an account of work sponsored by an agency of the United States Government. Neither the United States Government nor any agency thereof, nor Battelle Memorial Institute, nor any of their employees, makes any warranty, express or implied, or assumes any legal liability or responsibility for the accuracy, completeness, or usefulness of any information, apparatus, product, or process disclosed, or represents that its use would not infringe privately owned rights. Reference herein to any specific commercial product, process, or service by trade name trademark, manufacturer, or otherwise does not necessarily constitute or imply its endorsement, recommendation, or favoring by the United States Government or any agency thereof, or Battelle Memorial Institute. The views and opinions of authors expressed herein do not necessarily state or reflect those of the United States Government or any agency thereof.

\author{
PACIFIC NORTHWEST NATIONAL LABORATORY \\ operated by \\ BATTELLE \\ for the \\ UNITED STATES DEPARTMENT OF ENERGY \\ under Contract DE-ACO6-76RLO 1830
}




\section{DISCLAIMER}

Portions of this document may be illegible electronic image products. Images are produced from the best available original document. 


\section{Energy Vulnerability Relationships}

WHITE PAPER

Prepared for the Office of Fossil Energy (FE30)

U.S. Department of Energy

Brian R. Shaw

Jacob L. Boesen

Center for Environmental Security

Pacific Northwest National Laboratory

Washington, D.C.

February 1998 


\section{Executive Summary}

The US consumption of crude oil resources has been a steadily growing indicator of the vitality and strength of the US economy. At the same time import diversity has also been a rapidly developing dimension of the import picture. In the early 1970's, embargoes of crude oil from Organization of Producing and Exporting Countries (OPEC) created economic and political havoc due to a significant lack of diversity and a unique set of economic, political and domestic regulatory circumstances. The continued rise of imports has again led to concerns over the security of our crude oil resource but threats to this system must be considered in light of the diversity and current setting of imported oil. This report develops several important issues concerning vulnerability to the disruption of oil imports:

- The Middle East is not the major supplier of oil to the United States

- The US is not vulnerable to having its entire import stream disrupted

- Even in stable countries, there exist vulnerabilities to disruption of the export stream of oil

- Vulnerability reduction requires a focus on international solutions

- DOE program and policy development must reflect the requirements of the diverse supply

Does this increasing proportion of imported oil create a "dependence"? Does this increasing proportion of imported oil present a vulnerability to "price shocks" and the tremendous dislocations experienced during the 1970's? Finally, what is the vulnerability of supply disruptions from the current sources of imported oil? If oil is considered to be a finite, rapidly depleting resource, then the answers to these questions must be "yes." However, if the supply of oil is expanding, and not limited, then dependence is relative to regional supply sources.

This paper attempts to develop a strategy for evaluating the vulnerability of imports from a regional perspective. The process includes developing country specific incidents, creating oil export disruption scenarios and finally deriving quantitative vulnerability measures. These example vulnerabilities represent the reasonable focus for policy development. While it is apparent that the process yields reasonable results for this level of effort, they should be taken as proof-oi-principle rather than as final conclusions. Careful, coordinated scenario development is required before this process can be used for policy development. Nonetheless, several broad results appear to be quite clear and lead to important conclusions.

Far from a shortage of oil, when taken by region, oil supply to the United Sates is expanding and not concentrated in the hands of any one region, much less political or trade group. The largest individual supplier of crude oil to the US is Venezuela, and while nominally an OPEC member, is subject to regional vulnerabilities and challenges. What is also evident is the continued increase in exploration activity in the Western Hemisphere in spite of long-term, relatively low prices. It is apparent that short-term events and disruptions have a far less serious impact on total US imports than was evident in the past. The world is not running out of oil, and in fact, there is a significant increase in the diversity of supply sources. The most important conclusion from this preliminary study is that the US is not vulnerable to having its entire import stream disrupted.

In fact, the largest exporters to the US are from countries in the Western Hemisphere, Canada, Mexico and regions of South America, not the Middle East. With the inclusion of Mexico, Latin America is the chief exporting region to the US, providing over two times as much oil as the Middle East. This is due to exploration opportunities, both geologic as well as contractual. Many Western Hemisphere countries are willing to enhance risk-sharing contracts, reduce burdensome state participation clauses, and are encouraging US investment and development. The risk to US 
imports stems from political instability within each country and not the geopolitical stress of the 1970's OPEC embargoes.

Strategies to counter strategic vulnerabilities must be based on this supply reality. It is impossible to prepare to replace the entire import amount, but strategic vulnerability assessment will provide logical, timely and balanced investment strategies to protect the US from supply disruptions that create economic, political and energy crises. 


\section{TABLE OF CONTENTS}

EXECUTIVE SUMMARY .III

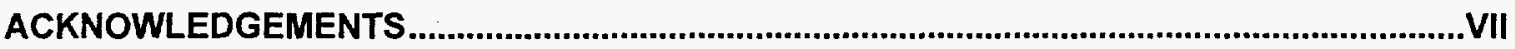

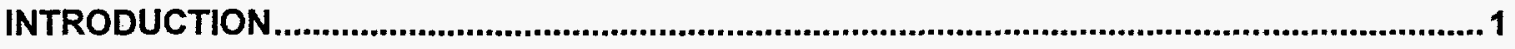

OIL IMPORTS

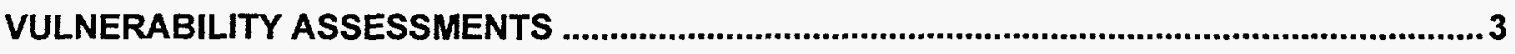

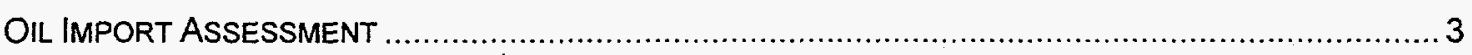

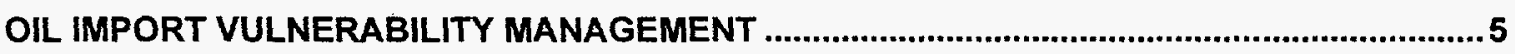

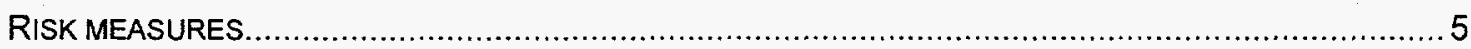

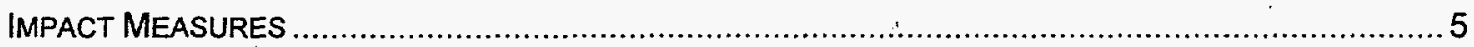

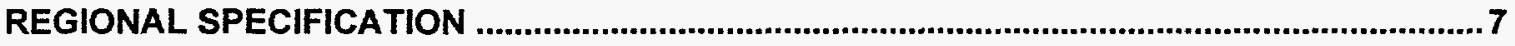

ORganization of OIL Producing Countries (OPEC); A Changed DYNAMIC ............................ 7

SCENARIOS FOR REGIONAL OIL IMPORTS............................................................................

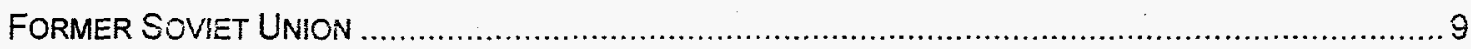

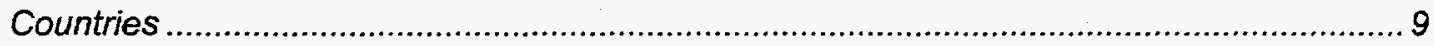

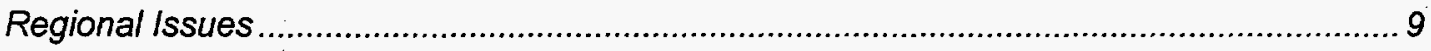

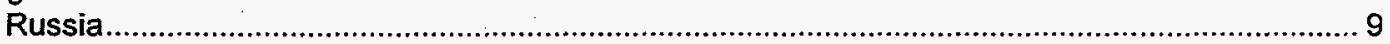

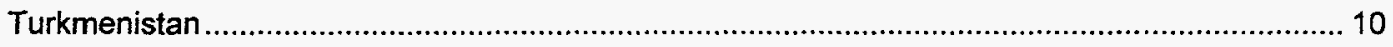

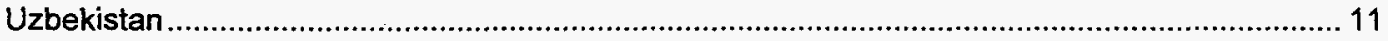

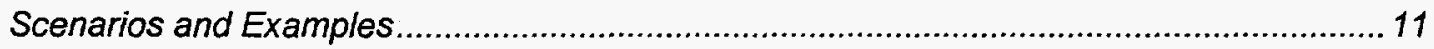

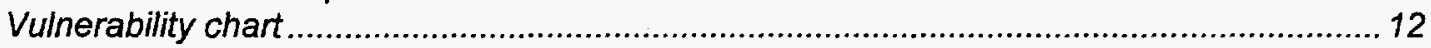

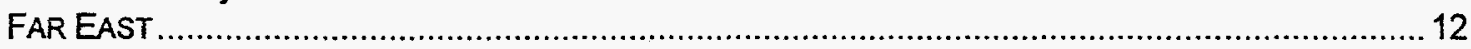

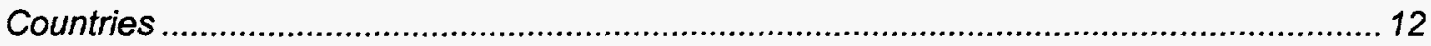

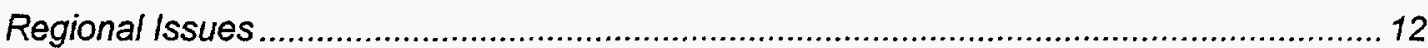

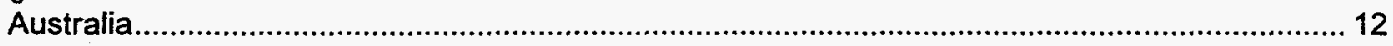

China

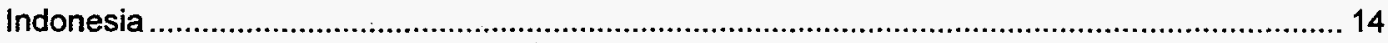

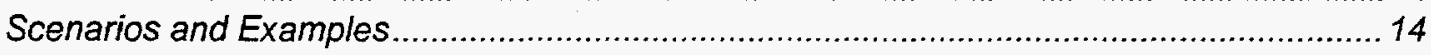

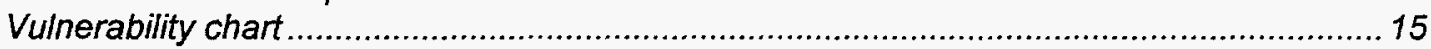

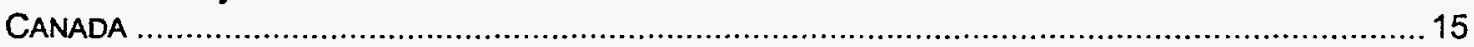

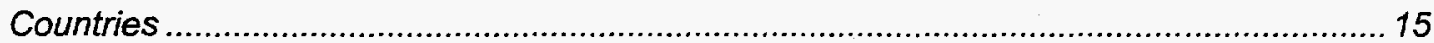

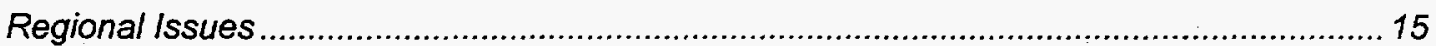

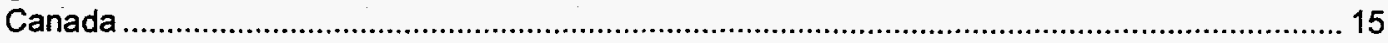

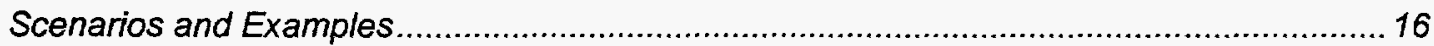

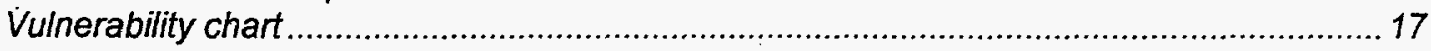

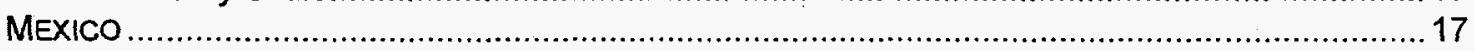

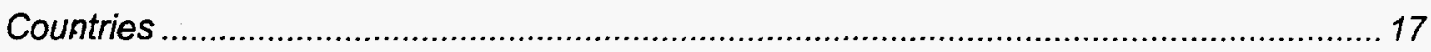

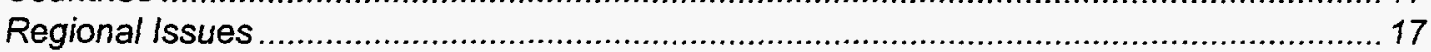

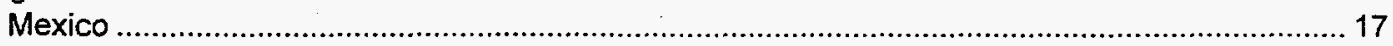

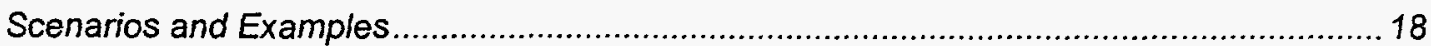

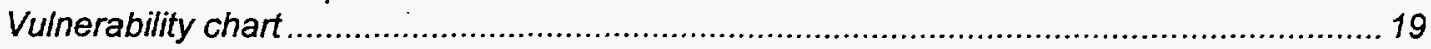

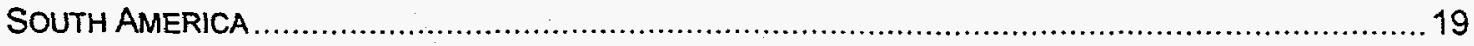




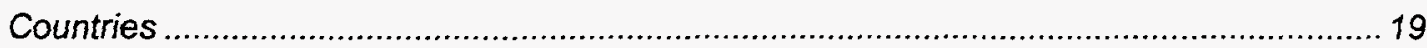

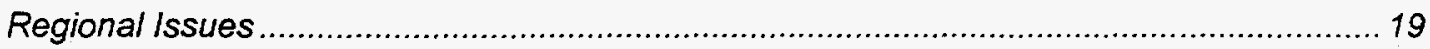

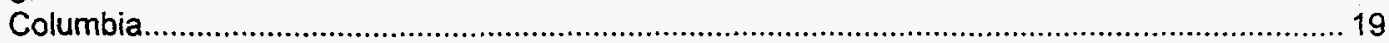

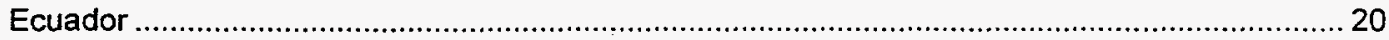

Peru

Venezuela

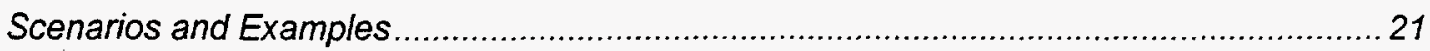

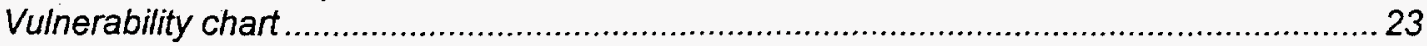

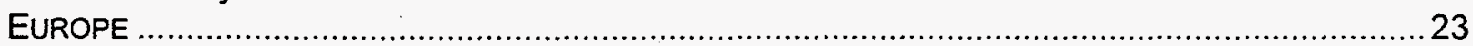

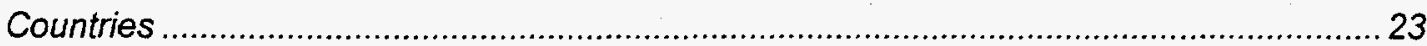

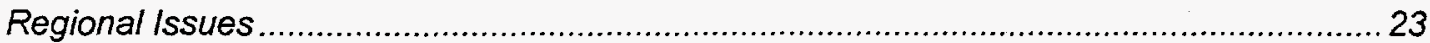

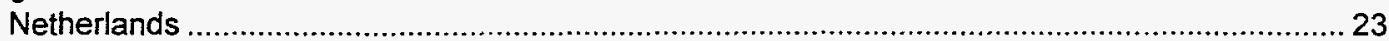

Norway

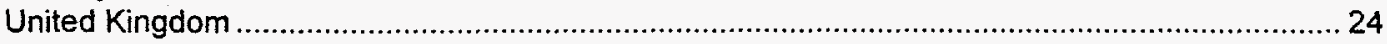

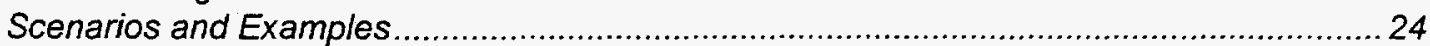

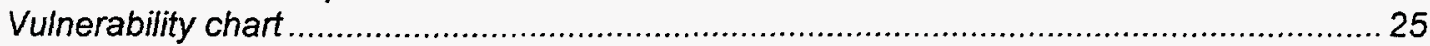

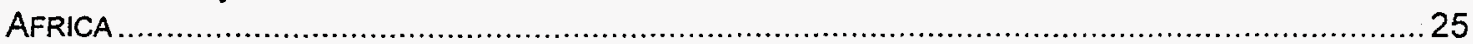

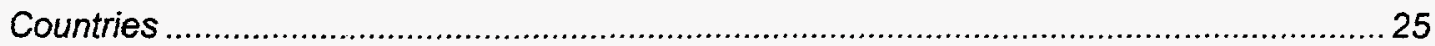

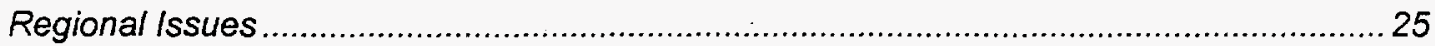

Algeria

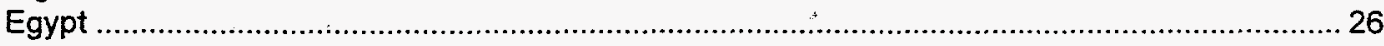

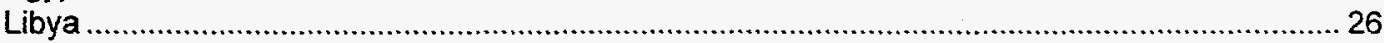

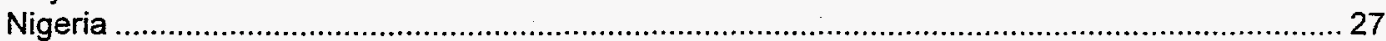

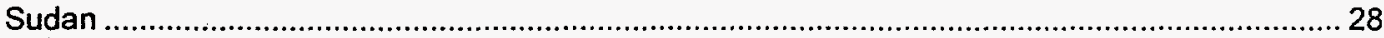

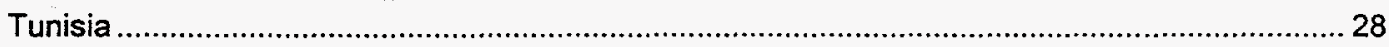

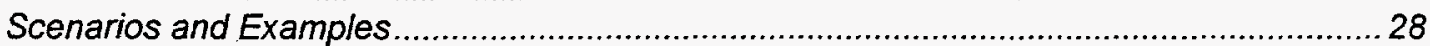

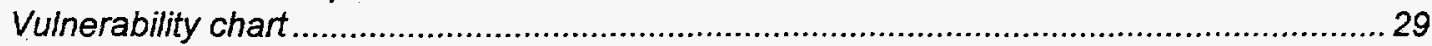

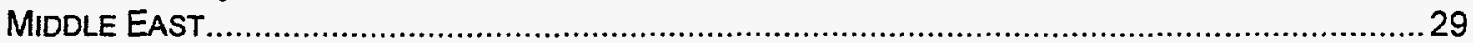

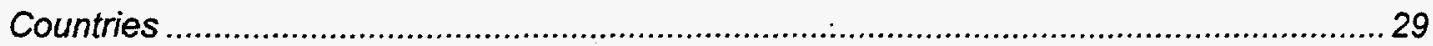

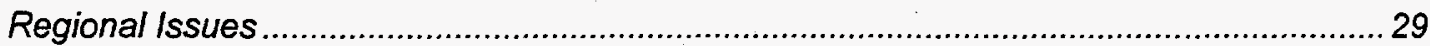

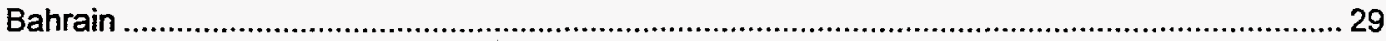

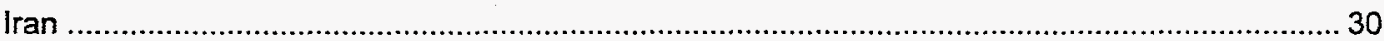

Iraq

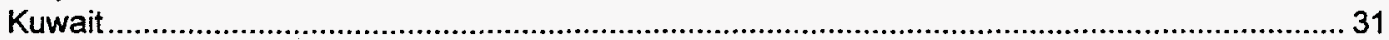

Oman

Qatar

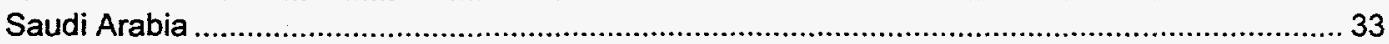

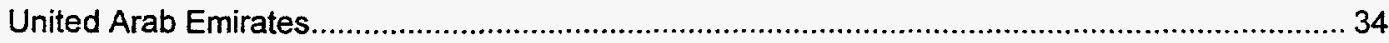

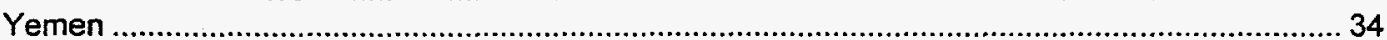

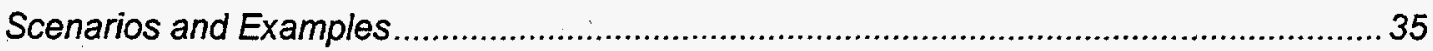

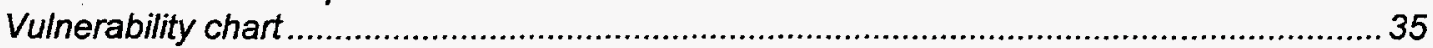

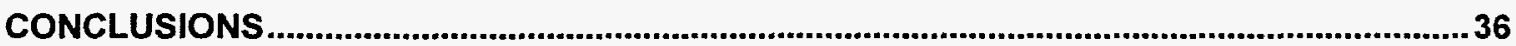

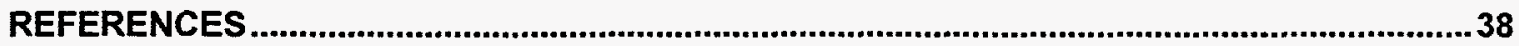

\section{TABLE OF FIGURES}

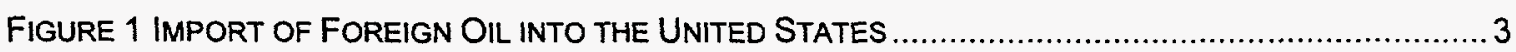

FIGURE 2 VULNERABILITY CURVE

FIGURE 3 THREAT REDUCTION

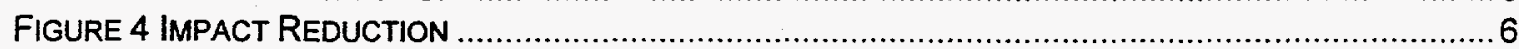

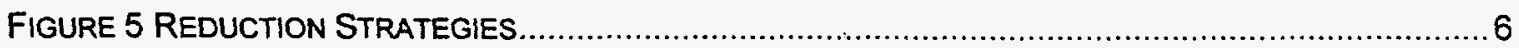

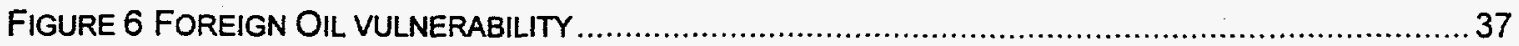




\section{Acknowledgements}

The authors would like to acknowledge the review and suggestions of Dr. Joe Roop, Ms. Karen Walker, Mr. Mike Farmer and Ms. Galina Sergen at the Pacific Northwest National Laboratory. Their insight and suggestions greatly assisted the presentation of these ideas. The authors would also like to acknowledge the discussions and insight provided by Mr. Peter Cover, DOE Office of Natural Gas and Oil Technology, Dr. J. Kenneth Schafer, DOE Office of National Security Policy, and Dr. Norm Kahn, Director of Assessments, DCI/EC. 


\section{Introduction}

The US Department of Energy is constantly engaged in the development of comprehensive energy strategies to define the basis as well as the plan of implementation for confronting the energy security of the United States. The current strategy is largely based on the recognition that the United States imports a significant proportion of its energy resources, primarily crude oil. Statements that claim that a 60 percent oil import dependency presents economic and national security concerns are common (c.f. Romm and Curtis, 1996). Constant reminders such as these create the impression that increasingly high levels of oil imports makes the U.S. vulnerable to supply disruption. The U.S. had historically been a net oil exporter, its reserve base being the basis for the commanding economic and industrial growth of the past 100 years as well as its military success in both world wars. With rapid growth of both the industrial and especially the transportation sector, the U.S. began to slowly, and then in the late 1960's rapidly, consume more crude oil than it was capable of producing. This consumption imbalance coupled with limited sources of imported oil, led to oil being used as a political weapon during the early 1970's. The Organization of Producing and Exporting Counties (OPEC) embargoes of the 1970's brought significant internal unrest, physical dislocation, and economic recession to the US. Some have placed the cost of OPEC embargoes at $\$ 4$ trillion (Greene and Leiby, 1993). In fact, the establishment of the Department of Energy was based on the concerns of this crisis period.

The US consumption of crude oil resources has been steadily growing reflecting the vitality and strength of the US economy. At the same time import diversity has also been a rapidly developing dimension of the import picture. In the early 1970's, embargoes of crude oil from Organization of Producing and Exporting Countries (OPEC) created economic and political havoc due to a significant lack of diversity and a unique set of economic, political and domestic regulatory circumstances. The continued rise of imports has again led to concerns over the security of our crude oil resource but threats to this system must be considered in light of the diversity and current context of imported oil.

This work was requested by the Office of Fossil Energy, Office of Natural Gas and Oil Technology. Brian Shaw and Jacob Boesen of the Center for Environmental Security at Pacific Northwest National Laboratory performed the analysis and interpretations based on procedures used in the analysis of regional environmental vulnerabilities and security issues. The purpose of the project is to develop a methodology that provides a description of oil import vulnerabilities at production sources. This process should assist the Office of Fossil Energy and the Department of Energy to develop pertinent and appropriate programs to counter the vulnerabilities imposed by the importation of crude oil. The paper is designed to be a proof-of-concept effort, demonstrating the applicability and general results that a detailed effort would provide. The scope of the project is limited to two basic elements: description of a methodology and interpretation of general vulnerabilities. This methodology will generate an understanding of oil import vulnerabilities and, provide an interpretation of general vulnerabilities facing the US that can be identified through this process.

The paper includes descriptions of country specific incidents, a few potential oil export disruption scenarios and example quantitative vulnerability measures. These example vulnerabilities represent a reasonable focus for policy development. While it is apparent that the process yields interesting results for this level of effort, careful, coordinated scenario development is required before this process can be used for policy development. Nonetheless, several broad results appear to be quite clear and lead to important conclusions. 


\section{Oil Imports}

Energy issues are a central component of most economies. The costs of energy, the ability to develop industrial economies and the trade in energy resources are clearly a major component of the economic factor. Evaluating energy issues separately from economic factors is fraught with peril. Most energy security assessments are in fact, economic assessments. If the question is one of a fungible resource, then the economic evaluations should define the balance of the flow of the resource.

Given the projections of domestic consumption and the naturally declining reserve base, it is clear that the proportion of imported oil will only continue to grow and domestic supply will diminish.

It is this continuing trend which concerns the comprehensive energy strategy. Many continue to sound the warning of potential disaster predicated on new OPEC cartel embargoes and disastrous price shocks to the US (Greene, 1996). The reserve to production ratio for some Persian Gulf countries is in excess of 130 years. In contrast, the US reserve to production ratio is less than 10 years. This huge imbalance of reserves and the economic control it generates appears on the surface to be the controlling factor in determining US vulnerabilities.

This report attempts to ask several questions of this assumption. Is there an identifiable preponderance of regional control of imported oil that creates a "dependence"? Does an increasing proportion of imported oil present a vulnerability to supply disruption? Are "price shocks" and the tremendous dislocations experienced during the 1970's likely? Finally, what is the vulnerability of supply disruptions from the current sources of imported oil? If oil is considered to be a finite, rapidly depleting resource, then the answers to these questions must be "yes" as the Middle East has a preponderance of proven reserves. However, if the supply of oil is expanding, and not limited, then dependence is relative to regional supply sources.

However, as has been seen in the past, oil is not necessarily a strictly depleting resource. In fact, petroleum resources respond to price increases and market opportunities (Adelman, 1989; Tippee, 1993). Far from a world shortage of oil, production figures and resource discoveries outside of the Middle East are increasing at surprising rates. What underlies this supply diversification is the continued rate of exploration. Investment and exploration activities are reflecting a response to perceived opportunity in spite of long-term, relatively low, price stability (Coy and McWilliams, 1997). It is apparent that short-term events and disruptions have a far more serious impact on prices than the overall supply of crude. The world is not running out of oil, but faces disruptions in supply.

The essential question asked in this report is to what extent is imported resource vulnerable to disruption from short-term events. The President's Commission on Critical Infrastructure Protection identified a five-step strategy for assessing and assuring critical national infrastructures. The first two steps include identification and categorization of threats and the consideration of vulnerabilities. The discussion of threats and risks includes the assessment of structured threats (national, terrorist, organized crime), unstructured threats (criminals, hackers, and vandals) and other risks (interdependencies, complexities, natural disasters or regulatory change). The analysis of vulnerability is the assessment of threats to physical systems and the potential impact on the other factors. In this context, security issues are focused on the relationship of the resource to compromise. To understand the larger picture of the US oil vulnerability, these threats must be viewed in terms of the sources of imported supplies, their magnitude, and susceptibility to disruptions. 
It is important to first examine the premise that the US is dependent on Middle East Oil. In fact, the US imports only 17.5 percent of its oil from the Persian Gulf. Imports from Mexico and the rest of Latin America total 40.5 percent of our imports! While there is no question that the US does and will continue to import significant percentages of its oil requirements, the assumption that the Persian Gulf is the dominant provider is clearly false (Figure 1).

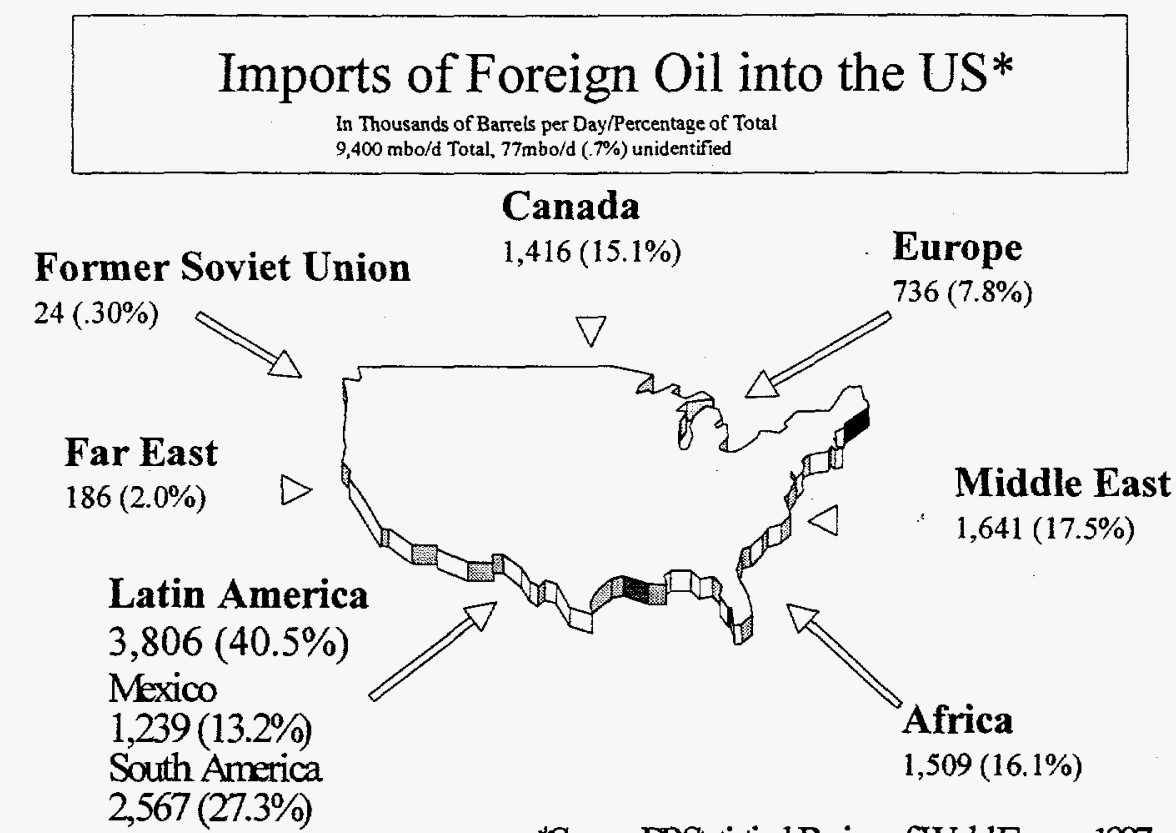

*Sauce BPStatisical Reviewof WridfEnergy, 1997

Figure 1 Import of Foreign Oil into the United States

\section{Vulnerability Assessments}

An understanding of the likelihood of resource flow disruptions to the United States requires an analysis of two issues. One critical factor is the ability of regional systems and resources to sustain production in the face of stress. The other not considered in this work, is the ability of other regions to supplant or replace withdrawn resources from other regions. This analysis focuses on the conditions within producing states. These vulnerabilities to export disruption must be identified and characterized to contribute to the development of a comprehensive energy strategy. Based on the likelihood and the impact of challenges to regional export production, the vulnerability of the system can be addressed. This assessment then can be used to assess both response and mitigation strategies for developing the framework and understanding of system vulnerabilities.

\section{Oil Import Assessment}

The current DOE Comprehensive Energy strategy builds on almost 20 years of asserting that the US is vulnerable to oil supply disruption simply due to an increasingly high level of oil imports. To make this assertion, the energy system must be simplified to specify crude petroleum imports to the US as the security issue. It is clear that the energy security of the US is far more complex 
than this issue alone, but this is the most easily grasped concept in public discussion. When stated in these terms, examining realistic export vulnerabilities within a broader energy system can assess potential supply disruptions. Disruptions of export of crude oil can arise from many sources, which will create widely varying impacts on that specific flow vector. For this reason, it is critical to establish the oil import stream under consideration. Vulnerabilities of oil production in Saudi Arabia are significantly different from those in the Canadian west.

Oil derived from any region can be subject to disruption by numerous scenarios: embargoes, warfare, political upheaval, infrastructure disruption, accidents and even inclement weather. The risk posed by each of these disruption scenarios can be estimated from past experience. The relationship between these scenarios and the impact of each element creates the framework for the determination of vulnerabilities. Given the amount of resource interrupted by each threat, a graph of the vulnerability for the region can be constructed (Figure 2).

\section{Oil Import Vulnerability}

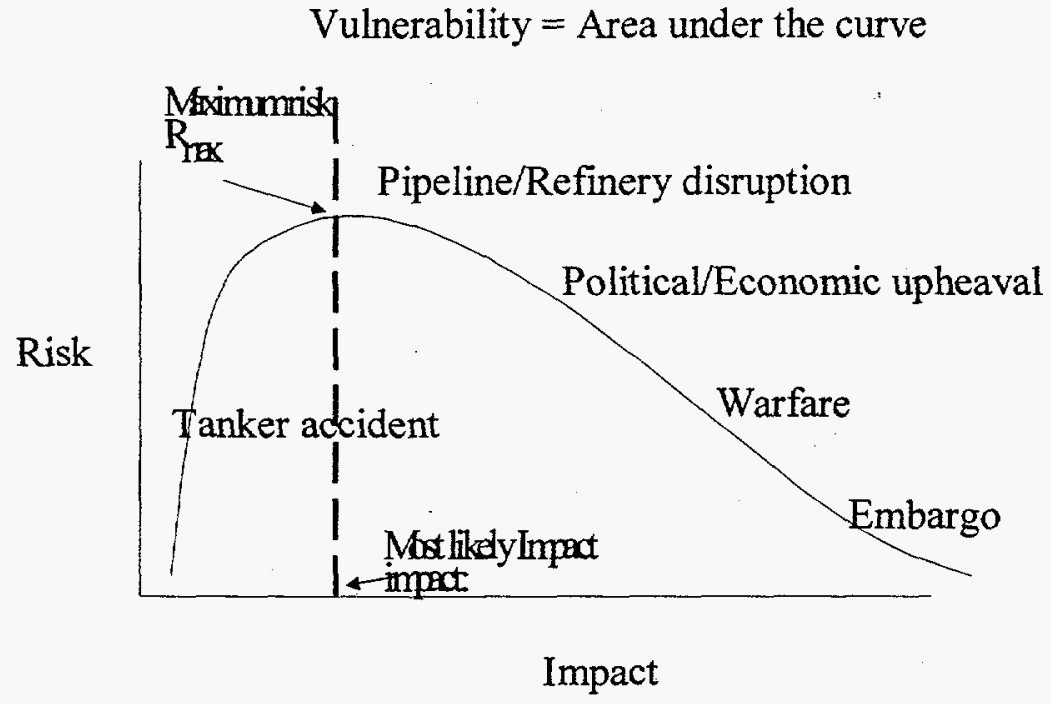

Figure 2 Vulnerability Curve

The curve is constructed by developing scenarios for potential oil disruptions and estimating the likelihood of occurrence. These scenarios can be constructed through any number of processes, the essential element is that they reflect the potential for disruption for a consistent region or stream of exports. These curves present a realistic estimate of vulnerability. The most likely vulnerability would be the most frequently occurring disruption. The most likely impact would be the modal value of the supply disruption curve. The area under the curve represents the vulnerability to supply disruptions for this region.

The initial assumption commonly made in assessments of oil supply is that the total export stream or some fractional portion is likely to be removed. While this attitude grew out of the embargoes of the 1970s, it is clear that there is a broad range of potential disruptions to oil supplies with an equally broad range of causes. These disruptions are regionally dependent, and highly contextual. Muslim factional tensions do not have an impact on Ecuadorian insurgencies. Disruptions in fact, occur frequently, but large supply disruptions are rare at best, none having occurred since the OPEC embargoes. Oil supply during the Gulf War serves as an example of rapid supply shifting and emergency response. 


\section{Oil Import Vulnerability Management}

The objective of managing energy issues is to reduce the area under the vulnerability curve. Given the two elements of the vulnerability curve, threat and impact reduction strategies can be developed appropriate for the system under consideration. Each scenario has components of risk that can be addressed to minimize the likelihood of occurrence, or conversely, the size of the impact of any threat can be countered through reducing the impact of a threat. An essential element of the analysis is the relative efficiency and applicability of an individual strategy in light of overall system vulnerability.

\section{Risk measures}

The first means of reducing the area under the vulnerability curve is to consider measures that reduce the risk of any or all of the individual threats. For example, measures can be developed to reduce the likelihood of terrorist attacks against pipelines and refineries. Diplomatic and foreign aid packages can be devised to support political elements of countries, dams can be constructed to store enough water to counter the effects of periodic El Ninõs, and so forth. Each of these measures attempts to reduce the risk dimension of the vulnerability curve (Figure 3 ).

\section{Threat Reduction}

Vulnerability decreases as risk

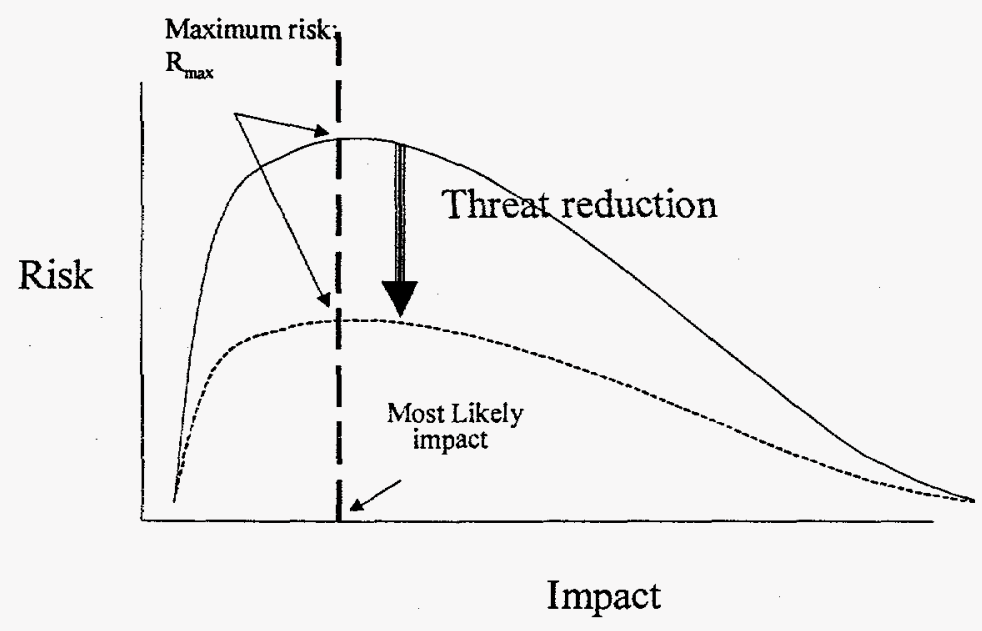

Figure 3 Threat Reduction

\section{Impact Measures}

The additional means of reducing the area under the vulnerability curve is to reduce the impact of any given threat. For example, technologies can be deployed that increase domestic oil production to counter the threat of supply disruption dependence. Oil storage facilities such as 
the Strategic Petroleum Reserve can be established to offset potential surge impacts of regional wars. Each of these measures has the effect of moving the curve to the left and given the same risks, reduces vulnerability (Figure 4).

\section{Impact Reduction}

Vulnerability decreases as impact

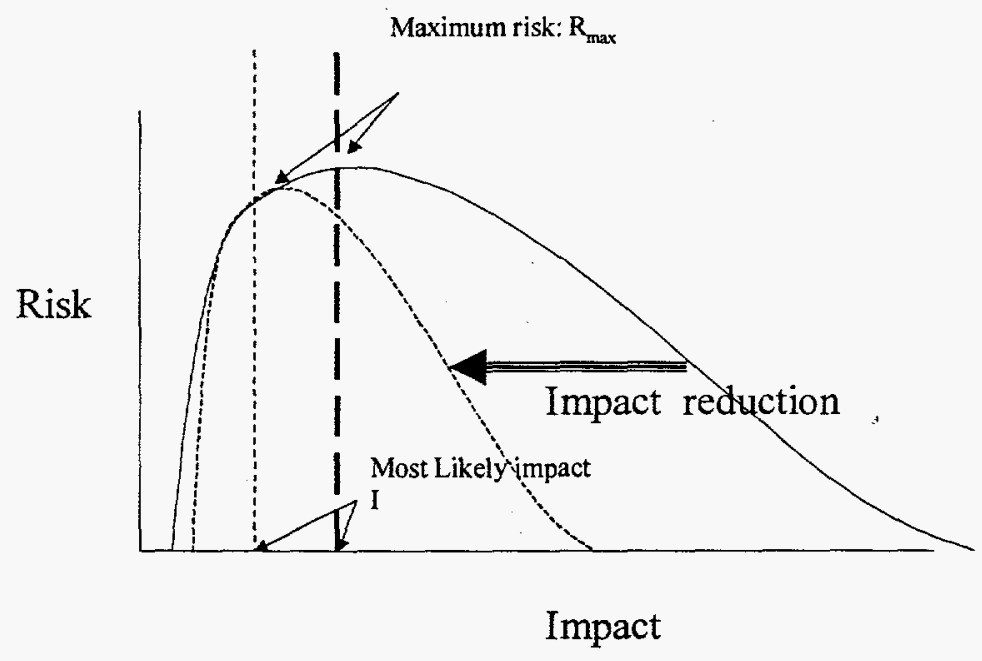

Figure 4 Impact Reduction

Each of these measures can work in concert or individually. The critical issue is the reduction of area under the vulnerability curve. Often these vulnerability reduction strategies have significantly differing costs and effectiveness (Figure 5).

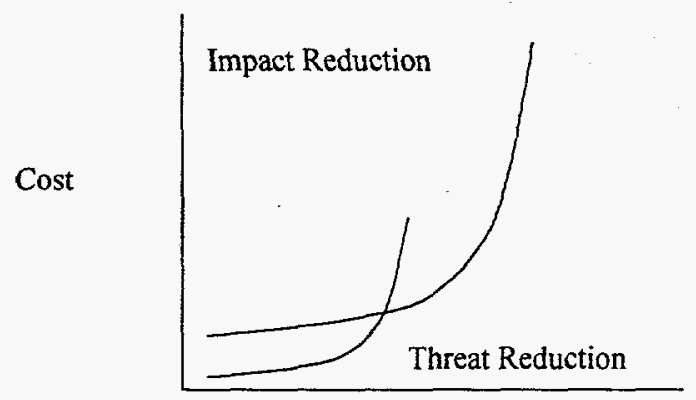

Vulnerability Reduction

Figure 5 Reduction Strategies

For example, the cost of providing safeguards and security for an installation such as a pipeline is very small for the relative reduction in threat, while the cost of providing additional oil reserves in the US becomes much more costly. Providing technology solutions to reducing impact 
vulnerabilities becomes extremely cost effective when applied to sources of oil as well as domestic reserves. This has the effect of providing impact reduction for other sources, but also improves the long-term durability of the supply. These two strategies can have very differing implementation curves.

Additional strategies can then be considered in conjunction with integrated assessments of additional elements. For example, given an understanding of oil import vulnerabilities, additional curves can be developed to assess internal distribution networks, other energy generation elements such as nuclear power plants or hydropower generation facilities and possibly the energy distribution grid. Each of these curves can be combined to reflect overall system vulnerability or, can provide individual focused strategic elements.

\section{Regional Specification}

Oil imports to the United States can be divided into several regional groupings typified by both geography and common transport routes. These groupings are important to understandings of the vulnerabilities as well as for the development of response strategies and policies. Each of these import vectors constitutes a vulnerable system to disruption and diversion. They can be defined as follows:

\begin{tabular}{|l|c|}
\hline \multicolumn{1}{|c|}{ Region } & $\begin{array}{c}\text { 1996 Imports to the US (thousand } \\
\text { bb/s./day) }\end{array}$ \\
\hline Former Soviet Union & 24 \\
\hline Far East & 186 \\
\hline Canada & 1416 \\
\hline Mexico & 1239 \\
\hline South America & 2567 \\
\hline Europe & 740 \\
\hline Africa & 1509 \\
\hline Middle East & 1641 \\
\hline
\end{tabular}

*Source: BP Statistical Review of World Energy, 1997

These regional groupings are critical to develop vulnerabilities and risks associated with supply disruptions. By grouping regional supply, transportation routes and "chokepoints" can be considered within the same framework. If organizational elements are used the analysis of transportation interruptions must take on a separate element.

These groupings were derived from considerations of similar political, cultural and economic relationships. For example, Mexico is considered separately from Latin America due to its proximity to the US and participation in the North American Free Trade Agreement (NAFTA). Venezuela is considered in its regional setting, as it shares pressures and threats to its infrastructure with its Latin American neighbors and not Persian Gulf states. The same argument is made for Southeast Asian countries.

\section{Organization of Oil Producing Countries (OPEC); A Changed Dynamic}

A traditional category commonly used in strategic analysis of oil security is the Organization of Oil Producing Countries (OPEC). Underscoring the criticality of employing and embracing this energy

\footnotetext{
'Other sources for import activities are relatively consistent with BP's. For example, the DOE EIA
} estimates are within $1 \%$ given rounding errors and regional definition differences. 
vulnerability formula is the reality that the preponderant US dependence on oil from OPEC in general, and Persian Gulf in particular, no longer exists. While it is arguable (Greene, 1996), OPEC as a bloc no longer wields or possesses the vast economic (and thus, political) force it enjoyed when it influenced global events through oil embargoes and fixed pricing in the 1970 s. This by no means indicates that OPEC is unimportant. In 1996 OPEC members expanded production by $2.8 \%$, with the largest volume increments from Venezuela (up $6.6 \%$ ) and Nigeria (up $8 \%$ ). The important issue is that the majority of OPEC increases are for markets other than the US, especially China and the Far East. There are a number of reasons for using geographic groupings rather than OPEC as an element. They, briefly, include:

- Emergence of Other Suppliers. One significant outcome of the 70 s oil embargoes by OPEC was the development and emergence of other supply sources. This is underscored by the fact that the total disruption of oil flow in the early stages of Desert Shield were hardly felt - if at all - in terms of adverse American economic impact. Other suppliers, in this case Saudi Arabia and the Strategic Petroleum Reserve provided a cushion and make up for the lost supply. Oil prices did rise for a very brief time, but there were no long lines at gas stations, shortages of critical fuels and economic readjustments. Today, imports of Persian Gulf oil account for only $17.5 \%$ percent of the total imports according to statistics compiled by British Petroleum and the Department of Energy (British Petroleum, 1997; IEA, 1997). As recent as 1986 OPEC oil accounted for $50 \%$ of US imported petroleum resources (IEA, 1997). This change alone is creates a staggering difference in the vulnerability of the US to OPEC actions.

- Non-adherence/Non-Concurrence to Supply Quotas and Prices. The major outcome of all of the above mentioned events and developments has been the preponderance of OPEC members to not adhere to or comply with agreed upon production quotas or "so-called" fixed prices. In fact, the inability of OPEC to "re-unify" since the 1970s has led to the withdrawal of Gabon and Ecuador as OPEC members (in 1992 and 1994 respectively). In addition, the emergence of what arguably is "opportunism" on the part of Venezuela in increasing its share of the US market is another critical weakness. In fact, today Caracas is the leading exporter of oil to States surpassing Saudi Arabia, which for years had held that pre-eminent position.

- Ascendancy of Islamic extremism. Evident in both the Shia and Sunni sects of Islam the extremist quarter of an overall renewal in Islamic fundamentalism and activism first surfaced with the revolution in Teheran in 1979. This pressure transformed the nation from a brutal monarchy to an equally repressive theocracy controlled by Shia mullahs and trusted lay politicians. One main theme of the new government was, and remains the export of Islamic revival to other countries in the Muslim world. There is an overt promotion of creating Islamic theocracies based upon the Sharia - or Islamic law. This policy has affected relations adversely with a number of neighbors to include the Gulf States of Iraq, Saudi Arabia, Bahrain, Qatar, Kuwait, and the United Arab Emirates. Each of these states -to a greater or lesser degree-- are now dealing with internal extremist movements and challenges to the political status quo, all stemming from revivalist roots.

- Iran-Iraq War. This is the first recorded war between two Islamic nations, a monumental turning point in Middle East solidarity and unity. The eight-year conflict, which began in 1981, drained the resources of the two combatants and placed pressure on the regimes to raise capital to support their respective war efforts. The war spilled over into Gulf oil shipping itself (e.g., the re-flagging of Kuwaiti tankers by the US to deter attack), and prevented any unanimous cartel posturing among the membership.

- Desert Shield/Desert Storm. Unlike the above mentioned conflict pitting Arab against Persian, this war was unprecedented in that it was one Arab nation aggressing against another. It was 
defended by both Arab and non-Arab combatants in a coalition - another culturally and politically significant event. Equally as profound was the cost. Kuwait was destroyed and while oil production has since returned to normal levels, costly rebuilding of infrastructure continues. A trade embargo (to include export of oil) continues relative to Iraq (less sales for exchange of humanitarian/relief supplies). Saudi Arabia, not nearly as economically potent even before the onset of hostilities, paid dearly to defend their borders and host the coalition invading force. All of these developments have also combined to smother and/or pre-empt any efforts toward cartel unity at the expense of self-interest.

The primary implications of these facts are that current OPEC motivations and internal pressures are not consistent with past embargo practice, and that any evaluation of exporting vulnerabilities must consider this regional context. This is not to imply that OPEC is irrelevant, its production and reserve base will make it permanently significant to world oil markets and economies. Understanding US vulnerabilities to import supply must consider more than price influence. Nonetheless, continuing regional difficulties and differences, as well as the further US diversification of non-OPEC, and, in particular, non-Persian Gulf oil sources will combine to restrict $\mathrm{OPEC}$ from regaining the influence it once enjoyed.

\section{Scenarios for Regional Oil Imports}

The following scenarios for regional oil-import vulnerabilities are based on cursory review of open source literature. They do not reflect an in-depth study of current regional factors. Background information used for this analysis has been derived from the CIA World Factbook for 1996, and Patterns of Global Terrorism, 1996 (Department of State, 1997). While the issues and directions of this paper are based on best available assessments, they may not reflect current strategic and political conditions as understood by the US government. The structure of the scenario text consists of exporting regional countries, a summary of country-based issues relevant to internal and external stability and relationships, and a few potential scenarios reflecting potential vulnerabilities and risks to our oil import flow. Environmental issues have been included from the World Factbook to reflect the sensitivity of center issues to energy production and transportation as well as the rising global sensitivity to the role of oil in the world's environment. This analysis is not intended to reflect an exhaustive scenario process. The listed vulnerabilities are illustrative only and should provide the basis for formal, detailed scenario development.

Regions in the analysis reflect the primary import geography of oil imports (Figure 1). These regions also have common characteristics, cultural similarities, and common challenges to stability and security.

\section{Former Soviet Union}

Countries

Russia, Turkmenistan, Uzbekistan

\section{Regional Issues}

\section{Russia}

International disputes: Inherited disputes from former USSR including sections of the boundary with China; islands of Etorofu, Kunashiri, and Shikotan and the Habomai group occupied by the Soviet Union in 1945, administered by Russia, claimed by Japan; maritime dispute with Norway over portion of the Barents Sea; Caspian Sea boundaries are not yet determined; potential dispute with Ukraine over Crimea; Estonia claims over 2,000 sq. $\mathrm{km}$ of Russian territory in the Narva and 
Pechora regions; the Abrene section of the border ceded by the Latvian Soviet Socialist Republic to Russia in 1944; has made no territorial claim in Antarctica (but has reserved the right to do so) and does not recognize the claims of any other nation.

Internal political climate/stability: Russia, a vast country with a wealth of natural resources, a welleducated population, and a diverse industrial base, continues to experience formidable difficulties in moving from its old centrally planned economy to a modern-market economy. The break-up of the USSR into 15 successor states in late 1991 destroyed major economic links that have been only partially replaced. As a result of these dislocations and the failure of the government to implement a rigorous and consistent reform program, output in Russia has dropped by one-third since 1990 (instead of the one-half previously estimated). On the one hand, the government has made substantial strides in converting to a market economy since launching its economic reform program in January 1992 by freeing nearly all prices, slashing defense spending, eliminating the old centralized distribution system, completing an ambitious voucher privatization program in 1994, establishing private financial institutions, and decentralizing foreign trade. On the other hand, Russia has made little progress in a number of essential areas that are needed to provide a solid foundation for the transition to a market economy. Moreover, the strong showing of the communists and nationalists in the Duma elections in December 1995 casts a shadow over prospects for further reforms. At the grass roots level, Moscow has yet to develop a social safety net that would allow faster restructuring by relieving enterprises of the burden of providing social benefits for their workers. Most rank-and-file Russians perceive they are worse off because of growing crime and health problems, the drop in real wages, the great rise in wage arrears, and the widespread threat of unemployment. The number of Russians living below the official poverty level rose by $10 \%$ to 36.6 million people, or $25 \%$ of the population. Amidst this political backdrop, Russia has struggled with a clearly out-of-control organized crime network and persistent reports of the availability of Russian military hardware for sale on the black market (to include nuclear material). The country has also been plagued recently by a series of bombs placed in public transportation vehicles in Moscow and elsewhere in the country as well as a bombing that leveled a nine-story apartment building in Kaspiysk, killing more than 50. Additionally, there is also the ever-present specter of activity from such ethnic separatist groups as the Chechen rebels. Internally, Russia has over $48,000 \mathrm{~km}$ of crude oil pipelines.

Current environmental issues: Air pollution from heavy industry, emissions of coal-fired electric plants, and transportation in major cities; industrial and agricultural pollution of inland waterways and sea coasts; deforestation; soil erosion; soil contamination from improper application of agricultural chemicals; scattered areas of sometimes intense radioactive contamination. Natural hazards: permafrost over much of Siberia is a major impediment to development; volcanic activity in the Kuril Islands; volcanoes and earthquakes on the Kamchatka Peninsula.

\section{Turkmenistan}

International disputes: Caspian Sea boundaries are not yet determined.

Internal political climate/stability: A fledgling independent state, Turkmenistan is ruled by a government and structure where formal opposition parties have been outlawed. Nonetheless, unofficial, small opposition movements exist underground or in foreign countries but no significant violent activities have occurred as a result of their existence to date. Turkmenistan is largely desert country with nomadic cattle raising, intensive agriculture in irrigated oases, and huge gas and oil resources. One-half of its irrigated land is planted in cotton making it the world's tenth largest producer. It also has the world's fifth largest reserves of natural gas and substantial oil resources. Until the end of 1993, Turkmenistan had experienced fewer economic disruptions than other former Soviet states because its economy received a boost from higher prices for oil and gas and a sharp increase in hard currency earnings. In 1994, Russia's refusal to export Turkmen gas to hard currency markets and mounting debts of its major customers in the former USSR for 
gas deliveries contributed to a sharp fall in industrial production and caused the budget to shift from a surplus to a slight deficit. The economy remained depressed through 1995 while inflation soared. Furthermore, with an authoritarian ex-communist regime in power and a tribally based social structure, Turkmenistan has taken a cautious approach to economic reform, hoping to use gas and cotton sales to sustain its inefficient economy. For the future, Turkmenistan will face continuing constraints on its earnings because of its customers' inability to pay for their gas and a below average cotton crop in 1995. Turkmenistan is working hard to open new gas export channels through Iran and Turkey, but these will take many years to realize.

Current environmental issues: Contamination of soil and groundwater with agricultural chemicals, pesticides; salinization, water-logging of soil due to poor irrigation methods; Caspian Sea pollution; diversion of a large share of the flow of the Amu Darya into irrigation contributes to that river's inability to replenish the Aral Sea; desertification.

Natural hazards: NA.

\section{$\underline{\text { Uzbekistan }}$}

International disputes: None.

Internal political climate/stability: Uzbekistan is a dry, landlocked country of which $10 \%$ consists of intensely cultivated, irrigated river valleys. It was one of the poorest republics of the former Soviet Union with more than $60 \%$ of its population living in overpopulated rural communities. At the same time, Uzbekistan is the world's third largest cotton exporter, a major producer of gold and natural gas, and a regionally significant producer of chemicals and machinery. Following independence, the government sought to prop up its Soviet-style command economy with subsidies and tight controls on production and prices. The authoritarian regime in control does face political opposition from the Birlik (Unity) People's Movement (BPM), and the Islamic Rebirth Party (IRP). The Erk (Freedom) Democratic Party was banned in December 1992.

Current environmental issues: Drying up of the Aral Sea is resulting in growing concentrations of chemical pesticides and natural salts; these substances are then blown from the increasingly exposed lake bed and contribute to desertification; water pollution from industrial wastes and the heavy use of fertilizers and pesticides is the cause of many human health disorders; increasing soil salinization; soil contamination from agricultural chemicals, including DDT. Natural hazards: NA

\section{Scenarios and Examples}

Russian oil interruptions

The oil spill near the town of Usinsk in Northern Russia (Komi republic) is one of the most serious environmental disasters of the decade. The ruptured pipeline is the third largest oil spill in history. Russia has more than a million miles of gas and oil pipelines, many of them poorly maintained. "Every year, up to a fifth of Russia's total oil production is lost - partly through theft, but much of it through leakage". Komineft, the company responsible for the 20-year-old pipeline, has a history of accidents caused by age and corrosion. Along the oil pipelines, which experience hundreds of leaks and ruptures each year, the ground is saturated with oil. Some of the oil has already seeped into the water table. The continuing scenario is of another serious breach of the primary pipe, with resultant interruption of flow. This potential disruption is based on the past as well as the continued lack of adequate operational maintenance of the system. It is highly likely that this disruption will occur, but with minimal disruption of supplies to the US. Probability: High (8). Impact: Very Low (5K BD)

\section{Caspian Region}

The conflict between Armenia and Azerbaijan threatens to disrupt not only the oil production slated off Baku's shores, but also the proposed pipeline route through the region. Additionally, the Azeri 
power struggle may end Turkey's influence in the region, which the western nations have been counting on as the moderating influence. Because it is questionable who will even rule Azerbaijan, any negotiations are less than definitive. Russia has been adamant regarding its desire to have the pipeline be routed through its southern territory to its Black Sea port of Novorossivsk. Supply disruptions to the US could occur if Russia interrupts the operations of the only pipeline connecting the existing fields to export. This scenario is moderately likely, as Russia has a history of utilizing trade in extracting strategic demands. In addition, the Chechnian situation makes this a more interesting possibility. Again, as the US imports little from this region, there will be little impact except as alternate sources are stressed. The future for exports from this region is very large and so vulnerability to transshipment infrastructure has the potential to disrupt future supplies. Probability: Medium (4). Impact: Very Low (2K BD)

A final possible, but remote scenario is that of the Russian government collapsing. One of the immediate potential results would be a full-scale civil war. Oil production would cease and resumption would be unlikely in the short term. The need for hard currency would eventually restore production, but as has been seen with the collapse of the Soviet Union, production without the necessary infrastructure investments would be at a still lower rate. Probability: Very Low (1). Impact: High (24K BD)

\section{Vulnerability chart}

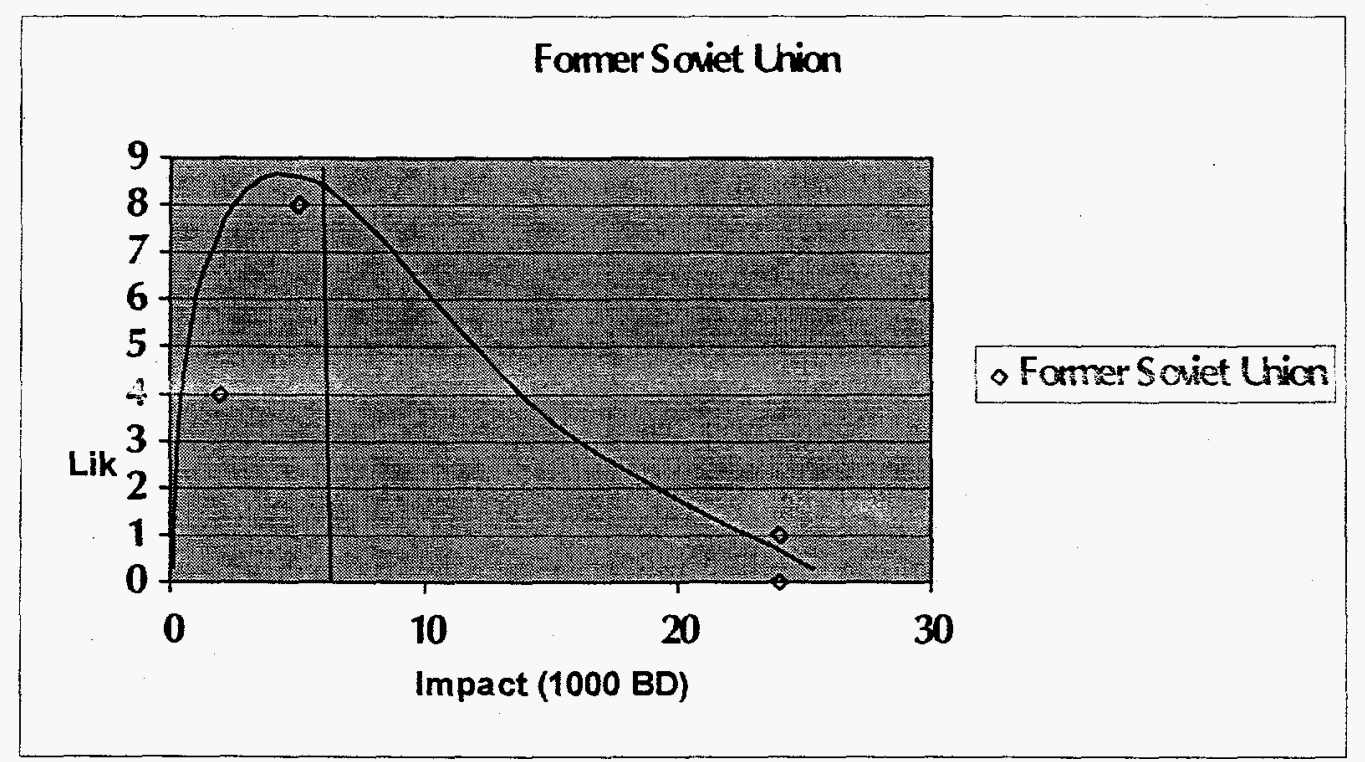

\section{Far East}

\section{Countries}

Australia, China, Indonesia

\section{Regional issues}

\section{Australia}

International disputes: Territorial claim in Antarctica (Australian Antarctic Territory).

Internal political climate/stability: No significant violent opposition to current rule exists within Australia. Alternative political opposition is present and includes the Australian Democratic Labor 
Party (anti-Communist Labor Party splinter group) and the Peace and Nuclear Disarmament Action (Nuclear Disarmament Party splinter group). Economically,

Australia has a prosperous Western-style capitalist system, with a per capita GDP comparable to levels in highly industrialized West European countries. Rich in natural resources, Australia is a major exporter of agricultural products, minerals, metals, and fossil fuels. Commodities account for more than $80 \%$ of the value of total exports, so that, as in 1983-84, a downturn in world commodity prices can have a big impact on the economy. The government is pushing for increased exports of manufactured goods, but competition in international markets continues to be severe. Australia has suffered from the low growth and high unemployment characterizing the OECD countries in the early 1990s. In 1992-93 the economy recovered slowly from the prolonged recession of 1990-91, a major restraining factor being weak world demand for Australia's exports. Growth picked up so strongly in 1994 that the government felt the need for fiscal and monetary tightening by year-end. Australia's GDP grew $6.4 \%$ in 1994, largely due to increases in industrial output and business investment. Like most advanced countries, Australia also contends with an organized criminal element and Tasmania is one of the world's major suppliers of licit opiate products. Accordingly, the government maintains strict controls over areas of opium poppy cultivation and output of poppy straw concentrate. Internally, Australia has over $2,500 \mathrm{~km}$ of crude oil pipelines.

Current environmental issues: Soil erosion from overgrazing, industrial development, urbanization, and poor farming practices; soil salinity rising due to the use of poor quality water; desertification; clearing for agricultural purposes threatens the natural habitat of many unique animal and plant species; the Great Barrier Reef off the northeast coast, the largest coral reef in the world, is threatened by increased shipping and its popularity as a tourist site; limited natural fresh water resources. Natural hazards: cyclones along the coast and severe droughts.

\section{China}

International disputes: Boundary with India in dispute; disputed sections of the boundary with Russia remain to be settled; boundary with Tajikistan in dispute; short section of the boundary with North Korea is indefinite; involved in a complex dispute over the Spratly Islands with Malaysia, Philippines, Taiwan, Vietnam, and possibly Brunei; maritime boundary dispute with Vietnam in the Gulf of Tonkin; Paracel Islands occupied by China, but claimed by Vietnam and Taiwan; claims Japanese-administered Senkaku-shoto (Senkaku Islands/Diaoyu Tai), as does Taiwan.

Internal political climate/stability: China has experienced little violent opposition to its rule since becoming a communist state. Democratic movements exist, but as Tianemen Square showed, even formal protest is quickly and summarily squelched with force by the government. Economically, Beijing has been anything but a copy of the traditional Marxist-Leninist model. Beginning in late 1978 the Chinese leadership has been trying to move the economy from a sluggish Soviet-style centrally planned economy to one that is more market-oriented, but still within a rigid political framework of Communist Party control. To this end the authorities switched to a system of household responsibility in agriculture in place of the old collectivization, increased the authority of local officials and plant managers in industry, permitted a wide variety of smallscale enterprise in services and light manufacturing, and opened the economy to increased foreign trade and investment. The result has been a strong surge in production. Agricultural output doubled in the 1980s, and industry also posted major gains, especially in coastal areas near Hong Kong and opposite Taiwan, where foreign investment and modern production methods helped spur output of both domestic and export goods. GDP has more than tripled since

1978. With the return of Hong Kong to Beijing's control, this figure promises to rise further. Despite tight government control, China is a major transshipment point for heroin produced in the Golden Triangle and the country is currently grappling with a growing domestic drug abuse problem. Internally, China's oil production is carried over $9,700 \mathrm{~km}$ of pipeline. 
Current environmental issues: Air pollution from the overwhelming use of high-sulfur coal as a fuel, produces acid rain which is damaging forests; water shortages experienced throughout the country, particularly in urban areas; future growth in water usage threatens to outpace supplies; water pollution from industrial effluents; much of the population does not have access to potable water; less than $10 \%$ of sewage receives treatment; deforestation; estimated loss of one-fifth of agricultural land since 1957 to soil erosion and economic development; desertification; trade in endangered species. Natural hazards: frequent typhoons (about five per year along southern and eastern coasts), damaging floods, tsunamis, earthquakes and droughts.

\section{Indonesia}

International disputes: Sovereignty over Timor Timur (East Timor Province) disputed with Portugal and not recognized by the UN; two islands in dispute with Malaysia.

Internal political climate/stability: Indonesia is a country with a government in tight control but one that still faces violent challenge from subversive groups. Mostly notably, last year 200 Free Papua Movement (OPM) guerrillas abducted 26 individuals in the Lorenta nature preserve Irian Jaya Province. The hostages were on a research expedition for the Worldwide Fund for Nature. Among the hostages were seven persons from the United Kingdom, he Netherlands, and Germany. The OPM demanded the withdrawal of Indonesian troops from Irian Jaya, compensation for environmental damage and for the death of civilians at the hands of the military, and a halt to Freeport Indonesia mining operations. On May15, Indonesian Special Forces members rescued the last nine hostages after locating them with a pilotless drone. Economically, Indonesia has a mixed system with some central planning but with an emphasis on rapid deregulation and private enterprise. Real GDP growth in 1985-95 averaged about $7 \%$, quite impressive, but not sufficient to both slash underemployment and absorb the 2.3 million workers annually entering the labor force. Plantation crops - rubber and palm oil - and textiles and plywood are being encouraged for both export and job generation. Industrial output is based on a supply of diverse natural resources, including crude oil, natural gas, timber, metals, and coal. Foreign investment has also boosted manufacturing output and exports in recent years. Indeed, the economy's growth is highly dependent on the continuing expansion of non-oil exports. Japan remains Indonesia's most important customer and supplier of aid. Like some other rapidly developing countries in Southeast Asia, Indonesia is struggling to keep the economy from overheating. Organized criminal elements in Indonesia are active as an illicit producer of cannabis largely for domestic use, but the government has actively eradicated plantings and prosecuted traffickers. Indonesia also plays a minor role as transshipment point for Golden Triangle heroin. Internally, the country has $2,505 \mathrm{~km}$ of crude oil pipelines.

Current environmental issues: Deforestation, water pollution from industrial wastes, sewage, air pollution in urban areas. Natural hazards: occasional floods, severe droughts, and tsunamis.

\section{Scenarios and Examples}

Oil Spill

On January 2, 1997, the Nakhodka, a Russian oil tanker, broke apart during stormy weather 80 miles off the coast of Japan's Shimane Prefecture. The tanker was carrying 133,000 barrels $(17,100$ tons) of fuel oil from China to Russia's Far East. Five days after the tanker broke apart in the Japanese Sea, the bow of the tanker ran aground on the rocky coastline of Japan's Fukui Prefecture, while the main body of the boat reportedly sank 2,500 meters to the bottom of the sea. It has been speculated that at least 5,000 tons of oil has leaked into the sea which has severely damaged marine wildife as well as other wildlife native to the Japanese Coast. Similar tanker accidents would have immediate response from Indonesia or China were they to occur in populated areas. The likelihood of this happening will only increase and the potential for supply interruptions to 
the US would result if transshipments to Japan were blocked or suspended. Probability: Medium (5). Impact: Low (10K BD)

\section{Human Rights Response}

The potential for China to invoke a cessation of oil exports, in addition to other goods, to the US in response to Washington criticism over human rights is a very real scenario. The US has not hesitated to express official condemnation stemming from a Beijing crackdown on democracy advocates in Beijing. A similar uprising of popular sentiment in Hong Kong would likely result in such sanctions, especially as Hong Kong represents a very tenuous political tie to China. Probability: Low (2). Impact: Low (10K BD)

Religious Insurgency

As in Persian Gulf countries, the potential for Muslim extremists to overthrow the civil regime in Indonesia is not unrealistic. Sales to western countries such as the US may be seen as a reasonable response to mollify Islamic extremists. Such a cut off of sales of oil to US would also effect countries such as Japan, which would stress alternate sources of petroleum. Probability: Very Low (1). Impact: Medium (94K BD)

\section{Vulnerability chart}

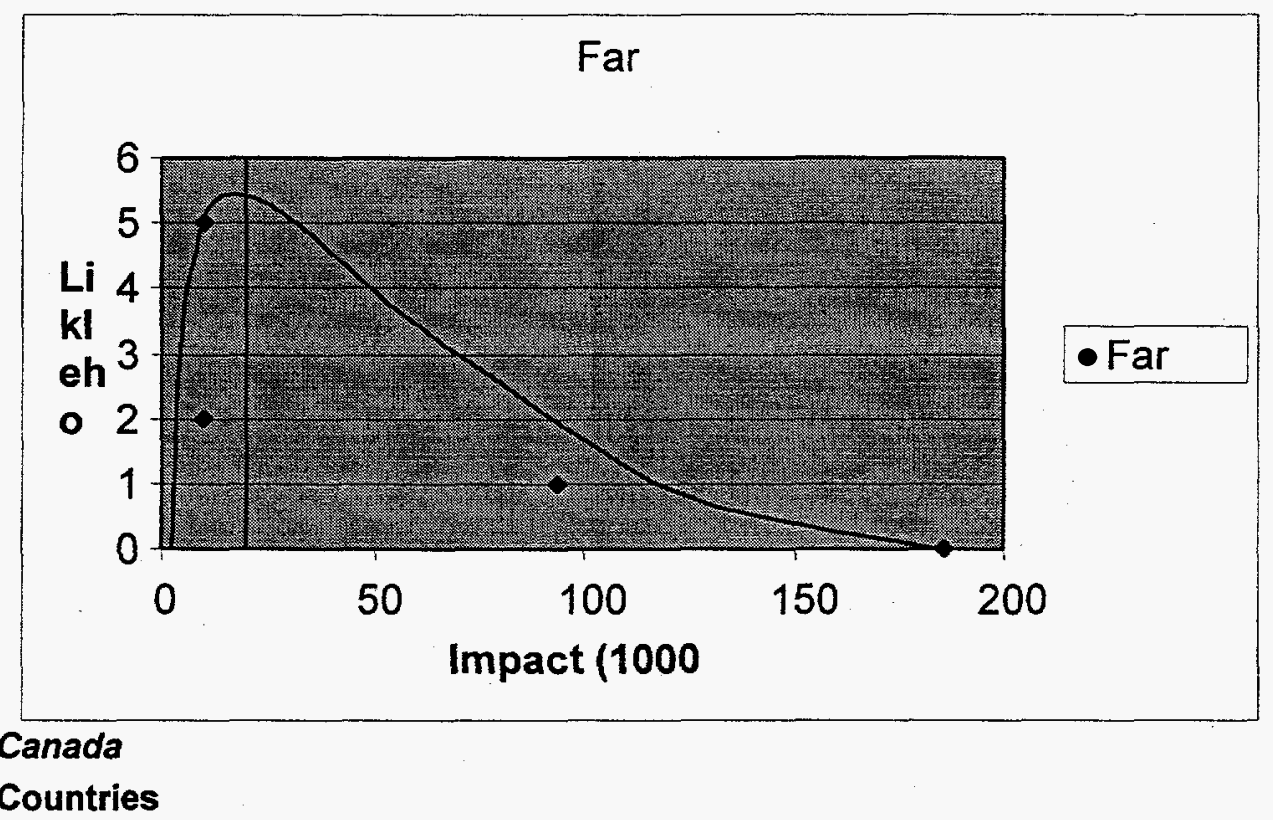

Canada

\section{Regional Issues}

\section{Canada}

International disputes: Maritime boundary disputes with the US; Saint Pierre and Miquelon is focus of maritime boundary dispute between Canada and France.

Internal political climate/stability: Canada suffers little from internal strife or instability. There is a contentious issue of Quebec separatism, but so far, issue has been largely confined to the 
legitimate political arena. The possibility of more direct action does exist however. Canada, like its neighbor to the south (the US), also has within its borders various cells of international terrorist organizations largely representing Islamic extremist or Palestinian causes. As an affluent, hightech industrial society, Canada today closely resembles the US in per capita output, marketoriented economic system, and pattern of production. Since World War II, the impressive growth of the manufacturing, mining, and service sectors has transformed the nation from a largely rural economy into one primarily industrial and urban. Canada started the 1990s in recession, and real rates of growth have averaged only $1.1 \%$ so far this decade. Because of slower growth, Canada still faces high unemployment and a large public sector debt. With its great natural resources, skilled labor force, and modern capital plant, however, Canada will enjoy better economic prospects in the future. The continuing constitutional impasse between English- and Frenchspeaking areas is raising the possibility of a split in the confederation, making foreign investors somewhat edgy. Canada is also home to criminal elements involved in the illicit drug trade to include the following activities: producer of cannabis for the domestic drug market; use of hydroponics technology permits growers to plant large quantities of high-quality marijuana indoors; growing role as a transit point for heroin and cocaine entering the US market. Internally, Canada has $23,564 \mathrm{~km}$ of crude and refined oil pipeline and almost $75,000 \mathrm{~km}$ of natural gas lines.

Current environmental issues: Air pollution and resulting acid rain severely affecting lakes and damaging forests; metal smelting, coal-burning utilities, and vehicle emissions impacting on agricultural and forest productivity; ocean waters becoming contaminated due to agricultural, industrial, mining, and forestry activities. Natural hazards: continuous permafrost in north is a serious obstacle to development; cyclones from east of the Rocky Mountains which are a result of the mixing of air masses from the Arctic, Pacific, and North American interior, and produce most of the country's rain and snow.

\section{Scenarios and Examples}

Quebec Separation

As the current constitutional crisis over Quebec separatism continues to develop, it is entirely likely that a vote for sovereignty will be successful. While Quebec does not represent oil imports to the US, it's hydroelectric sales to the US will need to be increased as a source of foreign trade. These increased sales may put downward impetus on Canadian exports to the US, partly in retaliation for conducting trade with Quebec or possibly as a result of the loss of the eastern Trans-Canadian pipeline terminal in Montreal. Probability: Low (2). Impact: Medium (700K BD)

In a more violent response to a failed separation vote, Quebec separatists bomb Canadian oil pipelines. Ten percent of US imports from Canada are disrupted. Probability: Low (3). Impact: Low (142K BD) 


\section{Vulnerability chart}

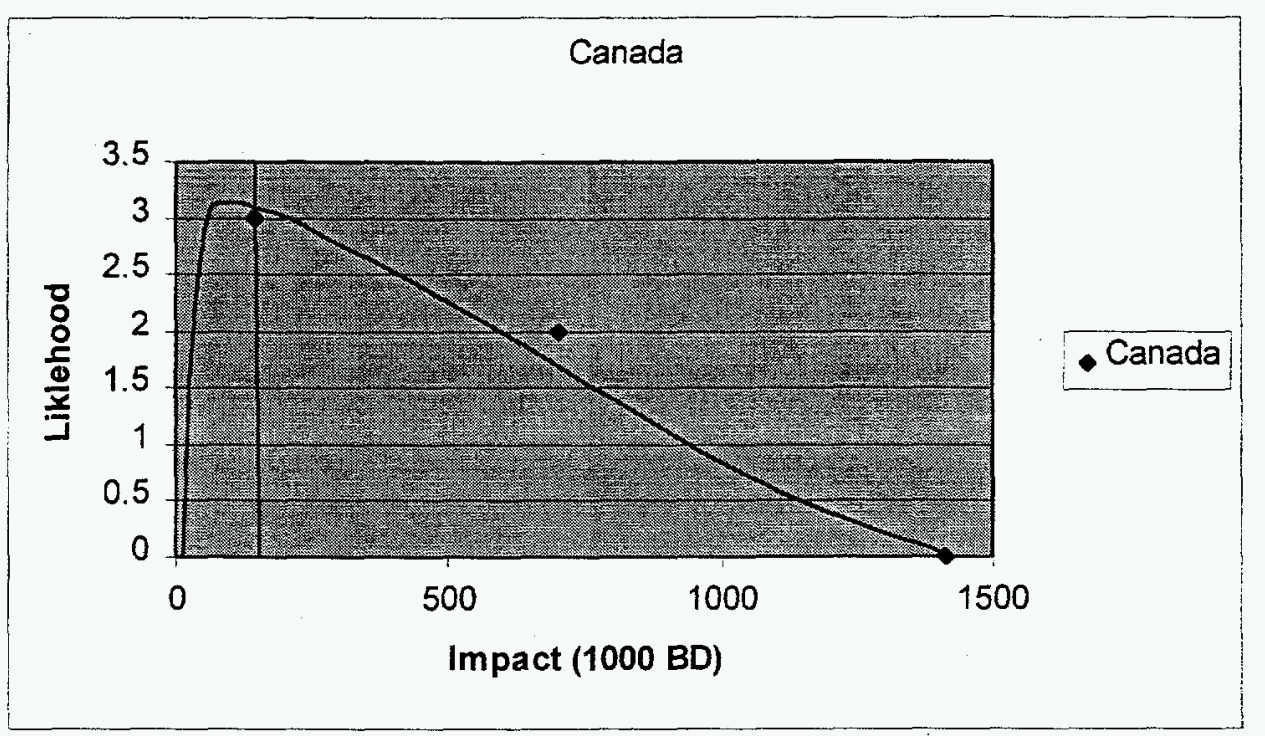

Mexico

Countries

Mexico

Regional Issues

Mexico

International disputes: Claims Clipperton Island (French possession).

Internal political climate/stability: Growing involvement confronting illicit drug trafficking, corruption, continuing economic problems, and suppressing emerging rebel movements are the major internal stability issues that highlight the political landscape in Mexico. All of these problems combine to provide a potential breeding ground for the evolution of more violent, unstable guerrilla movements as well as the continued attention of their US neighbors to the north. Relative to emerging terrorist groups, the self-proclaimed Popular Revolutionary Army (EPR) unveiled itself in the southwestern Guerrero State in June 1996 during a ceremony marking the anniversary of a state police massacre of local peasants. The EPR has conducted small-scale attacks in several states, mostly against Mexican military and police outposts, public buildings, and power stations. The group has killed at least 17 persons, including several civilians. The government has characterized the EPR as a terrorist group. The Zapatista National Liberation Army (EZLN), active in recent years, launched no violent attacks last year and in Fébruary EZLN representatives signed an agreement in southeastern Chiapas with the Mexican Government on the rights of indigenous people and made a commitment to negotiate a political settlement. Mexico has a free market economy with a mixture of modern and outmoded industry and agriculture, increasingly dominated by the private sector. Mexico entered 1996 on the heels of its worst recession since the 1930s. Economic activity contracted about $7 \%$ in 1995 in the aftermath of the peso devaluation in late 1994. Although Mexico City was able to correct imbalances in its external accounts, meet international payments obligations, and dramatically improve its trade balance in 1995, the domestic economy suffered harshly as the government stuck to a strict austerity 
program. The tight monetary and fiscal policies helped prevent spiraling inflation and kept government spending under control but drove interest rates to record heights, making it difficult for most Mexicans to service their debts. At the same time, consumers' reduced purchasing power made buying even necessities difficult for some. Many small- and medium-sized firms were unable to survive under the twin burdens of high interest rates and depressed domestic demand for their goods. Business closures and cutbacks fueled unemployment, more than 1 million Mexicans lost their jobs. According to the government and most private sector observers, the recession bottomed out in the third quarter of 1995, but the difficult year fed growing dissatisfaction with the ruling party, led to a crisis of confidence. While optimistic that 1996 will bring some recovery, the government is forecasting $3 \%$ growth and $21 \%$ inflation. Mexico will face several key vulnerabilities, including the financial health of the banking sector, shaky investor confidence that could be easily jarred by more political or economic shocks, and increasingly emboldened dissenters within the ruling party. Finally, the heretofore mentioned illicit drug trade includes the following activities: cultivation of opium poppy and cannabis continues in spite of increasing government eradication; major supplier of heroin and marijuana to the US market; continues as the primary transshipment country for US-bound cocaine from South America; increasingly involved in the production and distribution of methamphetamine. Internally, Mexico has $28,200 \mathrm{~km}$ of crude oil and $10,150 \mathrm{~km}$ of petroleum products pipelines.

Current environmental issues: Natural fresh water resources scarce and polluted in north, inaccessible and poor quality in center and extreme southeast; raw sewage and industrial effluents polluting rivers in urban areas; deforestation; widespread erosion; desertification; serious air pollution in the national capital and urban centers along US-Mexico border. Natural hazards: tsunamis along the Pacific coast, destructive earthquakes in the center and south, and hurricanes on the Gulf and Caribbean coasts.

\section{Scenarios and Examples}

Systemic Failure

It is conceivable that the Mexican federal government could collapse over public reaction to decades of corruption. The worst case scenario would indicate general insurrection as the country plunges into anarchy and economic ruin. Maintenance of oil exports would be impossible as PEMEX is seen as the very image of the PRI government and is sabotaged. Probability: Low (1). Impact: high (1239K BD)

Regional Instability

Based on the Tabasco rebellion, Mexican rebels attack refinery sites in Tabasco, temporarily disrupting production. Ten percent of US oil imports disrupted. Probability: Medium (4). Impact: Low (123K BD)

\section{Natural Disaster}

Earthquakes and volcanic eruptions are common events in Mexico. While the oil producing regions re not directly affected, as serious earthquake as in 1984, or a volcanic eruption (current) could totally destroy much of Mexico City and the DF, rendering petroleum production without management and oversight temporarily suspending supply. Probability: High (7). Impact: Low (10K BD) 


\section{Vulnerability chart}

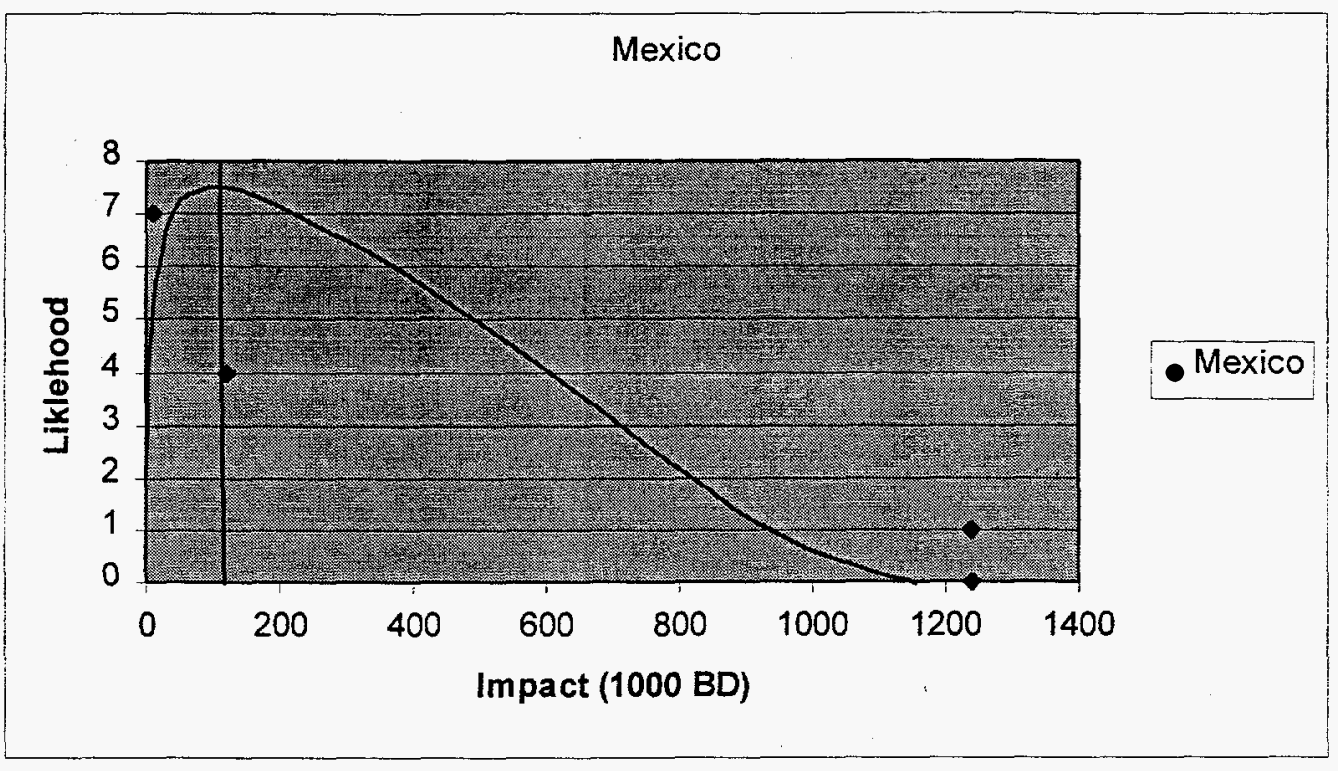

\section{South America \\ Countries}

Colombia, Ecuador, Peru, Venezuela

\section{Regional Issues}

\section{Columbia}

International disputes: Maritime boundary dispute with Venezuela in the Gulf of Venezuela; territorial dispute with Nicaragua over Archipelago de San Andres y Providencia and Quita Sueno Bank.

Internal political climate/stability: Colombia continues to grapple with widespread violence suffering numerous terrorist bombings, murders, kidnappings, and narcotics-related activity and bloodshed. Drug traffickers, leftist insurgents, paramilitary squads, and common criminals committed with impunity scores of violent crimes. Although most of the politically motivated violence was directed at domestic targets, Colombia recorded 66 international terrorist incidents during 1996, a drop from 76 such incidents in 1995. The most frequent targets of international terrorist attacks were the nation's oil pipelines, (about $3,600 \mathrm{~km}$ of line are at risk) which are operated in partnership with foreign oil companies. The nation's two main leftist insurgent groupsthe Revolutionary Armed Forces of Colombia (FARC) and the National Liberation Army (ELN)showed little interest in pursuing serious peace talks with the government, preferring to press their violent agenda. Throughout last year, ECOPETROL, the national Oil Company, was forced to shut down production repeatedly due to ELN attacks. Foreign oil company employees were kidnapped and held for ransom as part of the guerrillas' continuing war of terror against the Colombian oil industry. Just recently (October 1997), ELN terrorists grabbed six Ecopetrol employees and are currently holding them for ransom. Last year, ELN carried out 45 attacks against the oil pipeline, justifying its actions by claiming the government is giving away its precious oil reserves to foreigners. Despite all this, Columbia has a diversified and stable economy and has enjoyed Latin America's most consistent record of growth over the last several decades. 
Gross domestic product (GDP) has expanded every year for more than 25 years, and unlike many other South American countries, Colombia did not default on any of its official debts during the "lost decade" of the 1980s. Since 1990, when Bogota introduced a comprehensive reform program that opened the economy to foreign trade and investment, GDP growth has averaged more than $4 \%$ annually. Oil, with a large influx of direct foreign investment is now overtaking coffee as the leading export product. However, earnings from these commodities are probably far outdistanced by the illicit drug trade that produces coca, opium poppies, and cannabis. About 50,900 hectares of coca was under cultivation in 1995. The Colombian cartels combined are the world's largest processor of coca derivatives into cocaine and supplier of cocaine to the US and other international drug markets. An active aerial eradication program seeks to virtually eliminate coca and opium crops by the end of this year, but thus far, has not totally been successful.

Current environmental issues: Deforestation, soil damage from overuse of pesticides, air pollution, especially in Bogota, from vehicle emissions. Natural hazards: highlands subject to volcanic eruptions, occasional earthquakes, and periodic droughts.

\section{Ecuador}

International disputes: Three sections of the boundary with Peru are in dispute.

Internal political climate/stability: No serious insurgent movements are operational in Ecuador, but narco-traffikers do use the country as a transit hub for the movement of illicit drugs and to launder money. Economically, Ecuador has substantial oil resources and rich agricultural areas. Growth has been uneven in recent years because of fluctuations in prices for Ecuador's primary exports oil and bananas - as well as because of government policies designed to curb inflation. These measures helped to reduce inflation from $55 \%$ in 1992 to $25 \%$ in 1995.

Current environmental issues: Deforestation; soil erosion; desertification, water pollution. Natural hazards: frequent earthquakes, landslides, and volcanic activity, periodic droughts.

Peru

International disputes: Three sections of the boundary with Ecuador are in dispute.

Internal political climate/stability: Peru, like Columbia, has been another South American nation that has been perpetually confronted with responding to challenges from internal insurgents. While some signs of progress have been seen in recent years, the Peruvian Government's highly celebrated campaign against terrorism suffered a setback with the takeover of the Japanese Ambassador's residence in Lima in December 1996. In this attack, Tupac Amaru Revolutionary Movement (MRTA) terrorists captured more than 500 hostages, including eight US officials, numerous foreign ambassadors, prominent Peruvians (including the Foreign and Agriculture Ministers), six supreme court justices, high-ranking members of the police and military, and members of the Peruvian and international business community. The crisis ended earlier this year with a successful raid by Peruvian troops on the compound, but the damage to public perception on the government's ability to eradicate terrorism has lingered on. Peru's other major terrorist group, Sendero Luminoso (or Shining Path) was significantly weakened when its founder Abimael Guzman was arrested in 1992, but it has continued to carry out bombings and assassinations. In 1996, most Sendero terrorist violence took place in the Upper Huallaga and Apurimac Valleys, but even there, Army-sponsored self-defense militias helped counter the terrorists. There were two international terrorist incidents in Peru in 1996: a car bombing of a Shell oil warehouse in May (by Sendero) and the MRTA hostage seizure in December. Economically, Peru has become increasingly market-oriented, with major privatization completed since 1990 in the mining, electricity, and telecommunications industries. In the 1980s, the economy suffered from hyperinflation, declining per capita output, and mounting external debt. Peru was shut off 
from IMF and World Bank support in the mid-1980s because of its huge debt arrears. An austerity program implemented in July 1990 contributed to a third consecutive yearly contraction of economic activity, but the slide came to a halt late that year, and in 1991 output rose $2.4 \%$. Strong foreign investment helped push growth to $6 \%$ in 1993 , about $13 \%$ in 1994 , and $6.8 \%$ in 1995. Peru is also a source area for illicit drugs having the dubious distinction of being the world's largest coca leaf producer with about 115,300 hectares under cultivation in 1995; and source of supply for most of the world's coca paste and cocaine base.

Current environmental issues: Deforestation; overgrazing of the slopes of the Costa and

Sierra leading to soil erosion; desertification; air pollution in Lima; pollution of rivers and coastal waters from municipal and mining wastes natural hazards: earthquakes, tsunamis, flooding, landslides, and mild volcanic activity.

\section{Venezuela}

International disputes: Claims all of Guyana west of the Essequibo River, maritime boundary dispute with Colombia in the Gulf of Venezuela.

Internal political climate/stability: There are no significant domestic insurgent movements operating in Venezuela. However, border areas close to Columbia have been repeatedly attacked by the National Liberation Army (ELN) -- a Colombian terrorist group. Economically, the petroleum sector continues to dominate national output accounting for roughly $25 \%$ of GDP, $70 \%$ of total merchandise exports, and $45 \%$ of government revenue. Recently, US officials announced that Venezuela is now the number one exporter of petroleum to the States supplanted long time leader Saudi Arabia. As is the case in several other South American countries, Venezuela is a source area for the production and distribution of illicit drugs to include the cultivation of cannabis, opium, and coca leaf for the international drug trade on a small scale and as a major transit hub for large quantities of cocaine and heroin. Regarding the former, Venezuela is participating in an active aerial eradication program primarily targeting opium. Internally, the country has about $6,400 \mathrm{~km}$ of crude oil pipelines.

Current environmental issues: Sewage pollution of Lago de Valencia; oil and urban pollution of Lago de Maracaibo; deforestation; soil degradation; urban and industrial pollution, especially along the Caribbean coast. Natural hazards: subject to floods, rockslides, mud slides, periodic droughts.

\section{Scenarios and Examples}

Colombian internal instability

Not everyone in Colombia is pleased that the oil companies are drilling more and more in their country. The drug cartels, peasant groups and paramilitary groups have wrecked havoc on the oilpumping stations. Many of the oil wells are located in the "stomping ground" of the Medellin drug cartel as well as its competitors. The area is also the home to "the less publicized 'emerald wars' (Colombia produces 60 percent of the world emerald supply), to three separate groups of Marxist guerrillas and to an increasingly terrorist national police force seeking to quell the turmoil."

One reporter described a British Petroleum drilling site in the eastern foothills of the Andes as "an armed camp, swarming with khaki-clad, rifle-toting guards and surrounded by machine gun emplacements and two rows of flood-lit razor wire." The fortress is necessary in order to quell some of the violence caused by the Marxist guerrillas in the region who are protesting the eradication of coca crops. As it is difficult to halt the coca eradication process, the guerrillas attack the oil sites and pipelines as a demonstration of their dissatisfaction with the government's actions. 
The Marxist guerrillas of the National Liberation Army (ELN) and the Revolutionary Armed Forces of Colombia (FARC), which have made the nearby Cusiana and Cupiagua oil fields their prime target, are often blamed for the increase in violence. The groups "regularly blow up pipelines, kidnap foreign oil executives and kill local politicians in an attempt to force out multinational corporations and destabilize the Colombian economy." During the last nine years, "leftist guerrilla squads have dynamited Colombia's main oil pipeline 346 times, spilling slightly more than 1.2 million barrels of crude oil. The guerrillas seek publicity, rural development, and nationalization of the oil industry." The guerrillas also demand increased spending "for social programs in areas where the oil is produced."

Colombia's Environment Minister said, "no one has ever calculated how much the FARC owes" due to fears that the calculation would encourage the guerrillas to increase their destructive actions. During the past ten years, pipeline attacks by the guerrillas are estimated to have cost Colombia "about \$1 billion in lost oil sales." Ministry studies examining the years 1989 through 1991 "found that guerrilla pipeline bombings polluted 375 miles of creeks and rivers and fouled 12,500 acres, ranging from tropical wetlands to Andean watersheds." Continued action from leftist rebels that bomb multiple pipelines and mine oil shipping harbors in coordinated attack. Probability: Very Low (1). Impact: Medium (1500K BD)

Ecuadorian border disputes

Ecuador challenged the Rio Protocol in 1960 on the grounds that the "topography of the mountainous region was unknown when the border was set. As a result of Ecuador's objection, 50 miles of the 200-mile border were not marked, and both sides have moved in and out of the area since then, sometimes violently." Peru claims the eastern slopes of the range while the western slopes belong to Ecuador. The problem remains that "there is nothing in writing." The region is actually "unmapped jungle on the slopes of a remote mountain range--something not usually worth battling over." It is filled with "virgin forests, deep ravines and 4,000 foot mountains...shrouded in fog, and said to be virtually impossible to know where one side's stated border begins or ends." The two countries went to war in 1981 and most recently in January and February 1995. This boundary dispute results in regional war between Ecuador and Columbia cutting off export of oil from those two countries. Probability: Low (2). Impact: Medium (1000K BD)

Natural Disasters

Severe El Ninô related weather closes down and destroys shipping ports in Venezuela. Probability: Medium (3). Impact: Low (500K BD) 


\section{Vulnerability chart}

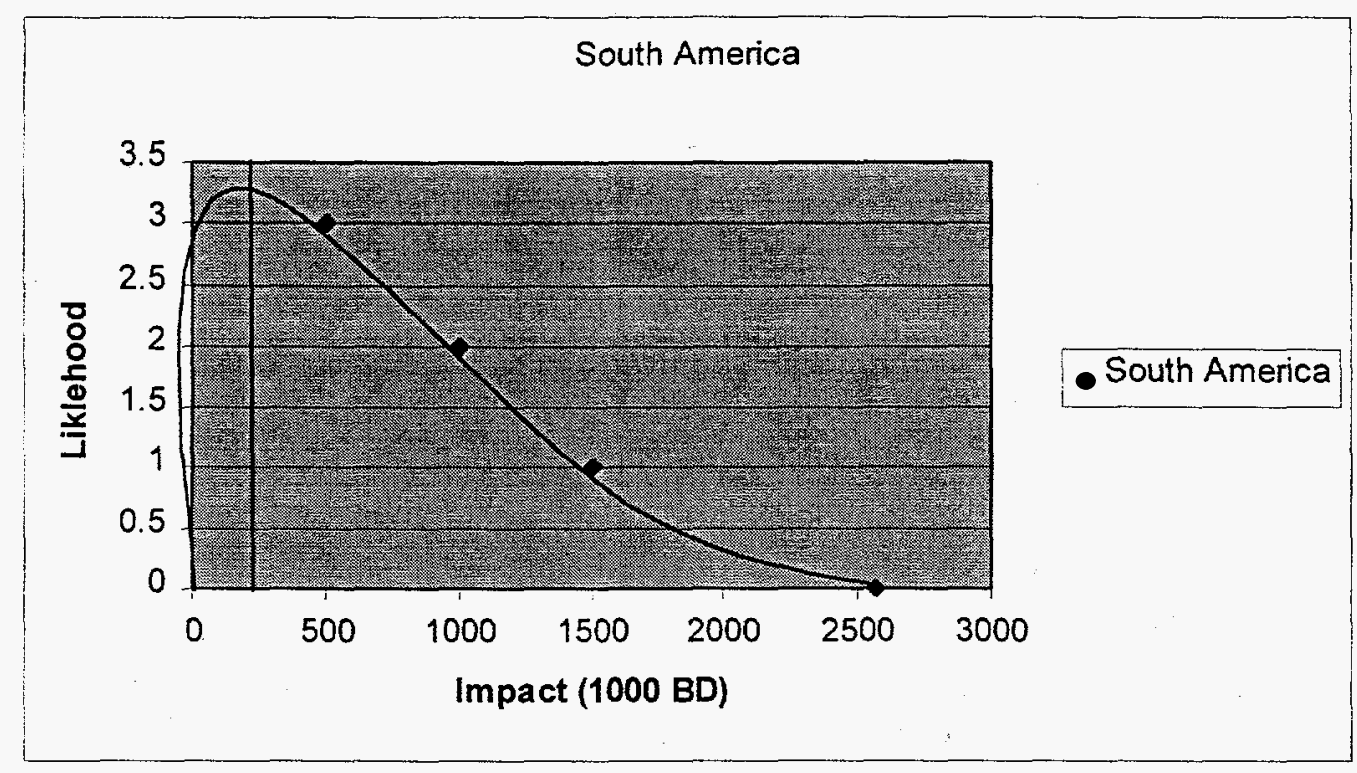

\section{Europe \\ Countries}

Netherlands, Norway, United Kingdom

\section{Regional issues}

\section{Netherlands}

International disputes: None.

Internal political climate/stability: Grassroots environmental movement exists but does not pose a threat to energy security resources. International presence of Middle East and Islamic extremists as well as Irish terrorists exists but none of these groups has targeted either the host government or energy resources.

Current environmental issues: Water pollution in the form of heavy metals, organic compounds, and nutrients such as nitrates and phosphates; air pollution from vehicles and refining activities; acid rain. Natural hazards: the extensive system of dikes and dams protects nearly one-half of the total area from being flooded

\section{Norway}

International disputes: Territorial claim in Antarctica (Queen Maud Land), maritime boundary dispute with Russia over portion of Barents Sea.

Internal political climate/stability: No significant internal problems. Occasional presence/transit of international terrorists, no activity noted.

Current environmental issues: Water pollution; acid rain damaging forests and adversely affecting lakes, threatening fish stocks; air pollution from vehicle emissions. 
United Kingdom

International disputes: Northern Ireland question with Ireland; Gibraltar question with Spain; Argentina claims Falkland Islands (Islas Malvinas); Argentina claims South Georgia and the South Sandwich Islands; Mauritius claims island of Diego Garcia in British Indian Ocean Territory; Rockall continental shelf dispute involving Denmark, Iceland, and Ireland (Ireland and the UK have signed a boundary agreement in the Rockall area); territorial claim in Antarctica (British Antarctic Territory).

Internal political climate/stability: The strongest and most stable constitutional monarchy within the community of nations. Despite that, has spent the most of this century grappling with the Northern Ireland question and attacks from the Provisional Irish Republican Army (PIRA). While these operations have focused traditionally on symbols of the British government, have recently expended to economic targets (but not those that are energy-related). London is also a base for Saudi dissidents as well as other Middle East extremists. Pro-Palestinian terrorists conducted operations within UK borders in the mid-Eighties, one event resulting in a severing of diplomatic ties with Syria. Libya has also been a focus of UK sanction owing to the discovery of arms assistance to the PIRA by Tripoli. Currently international terrorism activity in the UK is largely political vice operational. Beyond that, the British also have a large anti-nuclear and environmentalist movement, neither of which has resorted to criminal acts beyond minor acts of civil disobedience.

Current environmental issues: Sulfur dioxide emissions from power plants contribute to air pollution; some rivers polluted by agricultural wastes and coastal waters polluted because of large-scale disposal of sewage at sea.

\section{Scenarios and Examples}

Oil Spill

Numerous tanker accidents have occurred in the North Sea and the English Channel. Another massive oil spill near London could shut down North Sea shipping lanes. Environmental groups such as Greenpeace would then begin a focused political effort to eliminate oil production from these regions. Successful efforts could disrupt oil-shipping lanes for a long period. Probability: Low (3). Impact: Low (500K BD)

IRA Terrorism

Left wing autonomous cells dissatisfied with any talks with England could initiate a series of bombing attacks on NATO and European commercial pipelines. These pipelines have been attacked in the past and remain largely unprotected. Probability: Medium/High (7). Impact: Low (1K BD) 


\section{Vulnerability chart}

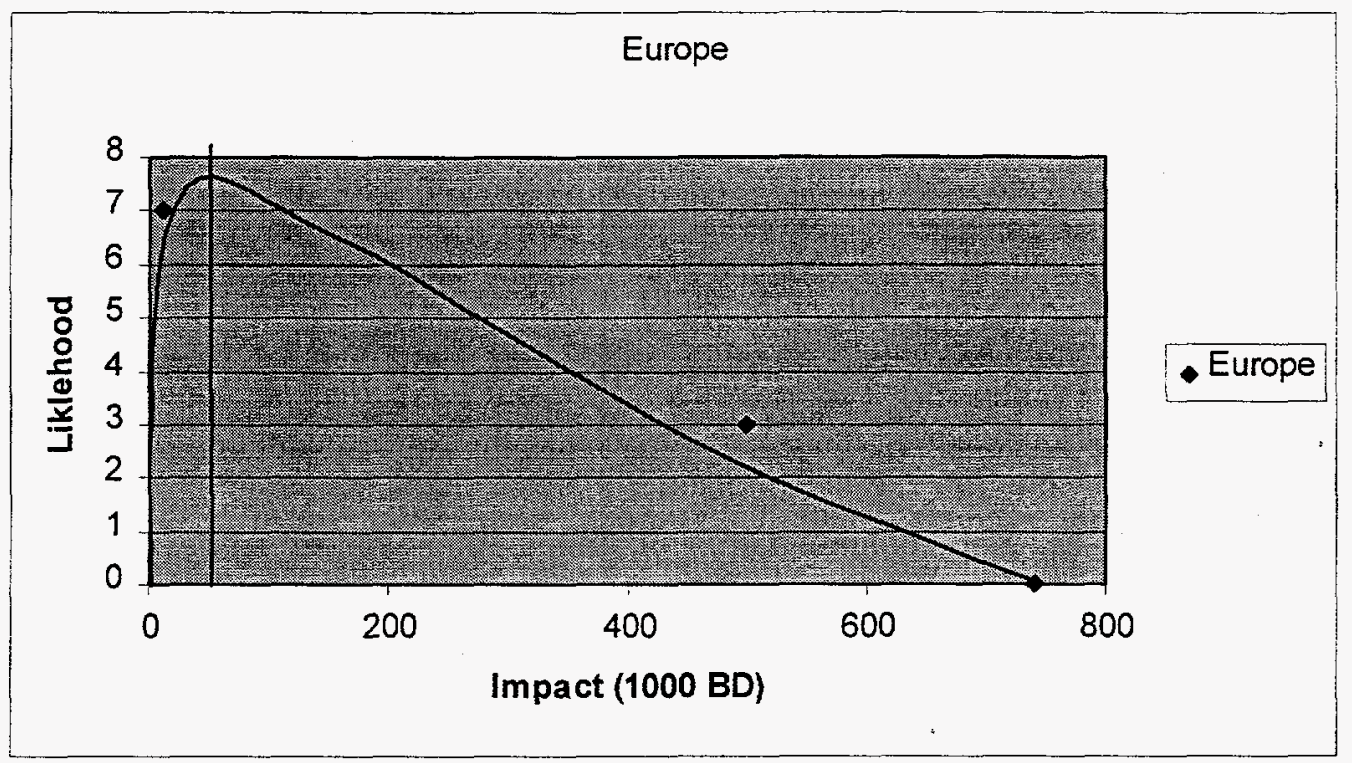

Africa

Countries

Algeria, Egypt, Libya, Nigeria, Sudan, Tunisia

\section{Regional Issues}

\section{Algeria}

International disputes: Part of southeastern region claimed by Libya; land boundary dispute with Tunisia settled in 1993.

Internal political climate/stability: Algeria is currently in the grips of a major insurrection. Coming as a result of a call for an Islamic state and on the heels of a less than successful effort at reform, the present regime in Algiers is being challenged by guerillas of the Islamic Salvation Front (outlawed in April 1992) and the Armed Islamic Group. Attacks on the populace have been uncategorically indiscriminate (sometime entire villages have been wiped out) and over 60,000 citizens, insurgents, and police have died as a result of the violence since 1992. Through last year, 110 foreigners have died because of attacks in the country. Algeria has the fifth-largest reserves of natural gas in the world and ranks fourteenth for oil. Algiers' efforts to reform one of the most centrally planned economies in the Arab world began after the 1986 collapse of world oil prices plunged the country into a severe recession. In 1989, the government launched a comprehensive, IMF-supported program to achieve economic stabilization and to introduce market mechanisms into the economy. Despite substantial progress toward economic adjustment, in 1992 the reform drive stalled as Algiers became embroiled in political turmoil. Should guerillas choose to deploy against energy resources, they have over $6,600 \mathrm{~km}$ of crude oil pipeline that they could remotely target. Thus far, however, the demonstrated focus of terrorist attacks has been people.

Current environmental issues: Soil erosion from overgrazing and other poor farming practices; desertification; dumping of raw sewage, petroleum refining wastes, and other industrial effluents is leading to the pollution of rivers and coastal waters; Mediterranean Sea, in particular, becoming 
polluted from oil wastes, soil erosion, and fertilizer runoff; inadequate supplies of potable water. Natural hazards: mountainous areas subject to severe earthquakes, mudslides.

Egypt

International disputes: Administrative boundary with Sudan does not coincide with international boundary creating the "Hala'ib Triangle," a barren area of 20,580 sq. $\mathrm{km}$, tensions over this disputed area began to escalate in 1992 and remain high.

Internal political climate/stability: Despite a constitutional ban against religious-based parties in the wake of the assassination of Anwar Sadat, the technically illegal Muslim Brotherhood constitutes President Hosni Mubarek's potentially most significant political opposition. Mubarek tolerated limited political activity by the Brotherhood for his first two terms but has moved more aggressively in the past year to block its influence. Tactically, the terrorist groups Al-Jihad and Gammat al Islamiya comprise the "action" cadres of Islamic extremist desires to undermine the Cairo regime and create an environment where upheaval would lead to a change in government and a transition to total Islamic law and rule. To this end, both groups have conducted extensive operations inside Egypt against a variety of targets; Gammat attempted the most significant attack to date in an external operation to assassinate Mubarek while on a state visit to Ethiopia. While still very problematic, Islamic extremist violence in Egypt actually fell in 1996. The number of fatalities-including noncombatants (105), police (59), and extremists (38) killed-fell sharply from 375 in 1995 to 202. Most incidents continued to occur in the provinces of Upper Egypt. In spite of improved security, however, al-Gama'at al-Islamiyya (Islamic Group or IG) succeeded in conducting a shooting attack against foreign tourists at a Cairo hotel in April. Although this hotel attack generated the largest casualty count from a single incident in Egypt's modern history, the total number of deaths from extremist violence dropped sharply in 1996 after increasing steadily during the previous four years. Economically, in 1986 the collapse of world oil prices and an increasingly heavy burden of debt servicing led Egypt to begin negotiations with the IMF for balance-of-payments support. Egypt's first IMF standby arrangement, concluded in mid-1987, was suspended in early 1988 because of the government's failure to adopt promised reforms. Egypt signed a follow-on program with the IMF and negotiated a structural adjustment loan with the World Bank in 1991. In 1991-93, the government made solid progress on administrative reforms such as liberalizing exchange and interest rates, but resisted implementing major structural reforms like streamlining the public sector. Consequently, the economy has not gained enough momentum to tackle the growing problem of unemployment. Egypt made uneven progress in implementing the successor programs it signed onto in late 1993 with the IMF and World Bank; currently it is negotiating another successor program with the IMF.

Current environmental issues: Agricultural land being lost to urbanization and windblown sands; increasing soil salinization below. Aswan High Dam; desertification; oil pollution threatening coral reefs, beaches, and marine habitats; other water pollution from agricultural pesticides, raw sewage, and industrial effluents; very limited natural fresh water resources away from the Nile which is the only perennial water source; rapid growth in population overstraining natural resources. Natural hazards: periodic droughts; frequent earthquakes, flash floods, landslides, volcanic activity; hot, driving windstorm called khamsin occurs in spring; dust storms, sandstorms.

\section{Libya}

International disputes: The International Court of Justice (ICJ) ruled in February 1994 that the 100,000 sq. km Aozou Strip between Chad and Libya belongs to Chad and that Libya must withdraw from it by 31 May 1994; Libya has withdrawn some of its forces in response to the ICJ ruling, but still maintains part of the airfield and a small military presence at the airfield's water supply located in Chad; maritime boundary dispute with Tunisia; claims part of northern Niger and 
part of southeastern Algeria. Libya is also one of the current state sponsors of terrorism as annually assessed by the US Department of State.

Internal political climate/stability: Since Colonel Muamar Qaddafi's takeover in Tripoli, the country has been ruled under the Jamahiriya (a state of the masses) which in theory is government by the populace through local councils. In fact, however, Libya has been tightly and charismatically led via a military dictatorship headed by Qaddafi and a small circle of trusted confidants and relatives. Recently there has been evidence of emerging political or pressure groups primarily consisting of various Arab nationalist movements but with an almost negligible membership. Most function clandestinely. In addition, some Islamic extremist elements have gained a footing inside Libya and could pose an eventual challenge to the secular regime. Economically, the socialist-oriented economy depends primarily upon revenues from the oil sector, which contributes practically all export earnings and about one-third of GDP. In 1990, per capita GDP was the highest in Africa at $\$ 5,410$, but subsequently GDP growth has slowed on average and has fluctuated sharply in response to changes in the world oil market. Import restrictions and inefficient resource allocations have led to periodic shortages of basic goods and foodstuffs. Libya's energy production infrastructure includes over $4,383 \mathrm{~km}$ of crude oil pipeline as well as several US built oil extraction facilities.

Current environmental issues: Desertification; very limited natural fresh water resources; the Great Manmade River Project, the largest water development scheme in the world, is being built to bring water from large aquifers under the Sahara to coastal cities.

Natural hazards: hot, dry, dust-laden ghibli is a southern wind lasting one to four days in spring and fall; dust storms, sandstorms

\section{Nigeria}

International disputes: Demarcation of international boundaries in vicinity of Lake Chad, the lack of which led to border incidents in the past, is completed and awaits ratification by Cameroon, Chad, Niger, and Nigeria; dispute with Cameroon over land and maritime boundaries in the vicinity of the Bakasi Peninsula has been referred to the ICJ.

Internal political climate/stability: The oil-rich Nigerian economy continues to be hobbled by political instability, corruption, and poor macroeconomic management. Nigeria's unpopular military rulers failed to make significant progress in diversifying the economy away from over-dependence on the capital intensive oil sector which provides almost all foreign exchange earnings and about $80 \%$ of budgetary revenues. Regime officials also appear divided on how to redress fundamental economic imbalances that result in troublesome inflation, the steady depreciation of the naira, and the discouragement of investors. The government's domestic and international arrears continue to limit economic growth and prevent an agreement with the IMF and bilateral creditors on debt relief. The largely subsistence agricuitural sector has failed to keep up with rapid population growth, and Nigeria, once a large net exporter of food, now must import food. Nigeria also has a profound reputation in the area of organized crime. In the area of illicit drugs, Nigeria's role as a passenger and cargo air hub for West Africa is used by criminal elements to facilitate the movement of heroin en route from Southeast and Southwest Asia to Western Europe and North America. It is also increasingly a transit route for cocaine from South America intended for West European, East Asian, and North American markets. Internally, the country has $2,042 \mathrm{~km}$ of crude oil pipeline.

Current environmental issues: Soil degradation; rapid deforestation; desertification, recent droughts in north severely affecting marginal agricultural activities. Natural hazards: periodic droughts 
Sudan

International disputes: Administrative boundary with Kenya does not coincide with international boundary; administrative boundary with Egypt does not coincide with international boundary creating the "Hala'ib Triangle," a barren area of $20,580 \mathrm{sq}$. $\mathrm{km}$, tensions over this disputed area began to escalate in 1992 and remain high. Sudan is also one of the current states sponsors of terrorism as annually assessed by the US Department of State.

Internal political climate/stability: The Sudanese government is dominated by members of Sudan's National Islamic Front, a fundamentalist political organization formed from the Muslim Brotherhood in 1986; front leader Hasan al-Turabi dominates much of Khartoum's overall domestic and foreign policies. In their role as a sponsor of terror, Sudan has played host to such notorious international terrorists as Usama bin Laden as well as a host of Islamic extremist groups who use the country as a safe haven and training ground. As a result of this activity and danger to American citizens, US diplomatic representation: operations in Khartoum were suspended in February 1996. In the south, Sudan is buffeted by civil war where a Muslim minority is slaughtering a non-Muslim majority population. These issues plus adverse weather, high inflation, a drop in remittances from abroad, and counterproductive economic policies have combined to make Sudan a highly volatile and internally unstable country.

Current environmental issues: Inadequate supplies of potable water; wildlife populations threatened by excessive hunting; soil erosion, desertification. Natural hazards: dust storms.

\section{Tunisia}

International disputes: Maritime boundary dispute with Libya; land boundary dispute with Algeria settled in 1993; Malta and Tunisia are discussing the commercial exploitation of the continental shelf between their countries, particularly for oil exploration.

Internal political climate/stability: Like many regimes in the region, The Tunis government is being politically pressured and challenged by an Islamic fundamentalist party, in this case, An Nahda (Rebirth), which has incidentally been outlawed. Some violent activity has occurred in the name of Islamic resistance but, to date, not at nearly the same level or intensity as in other African or Middle East countries where similar movements exist.

Current environmental issues: Toxic and hazardous waste disposal is ineffective and presents human health risks; water pollution from raw sewage; limited natural fresh water resources; deforestation; overgrazing; soil erosion; desertification. Natural hazards: NA

\section{Scenarios and Examples}

Political Revolt

Given the political unsuitability of the region, Muslim extremists could overthrow the secular regimes in Libya, West Africa and Algeria in a coordinated multi-coup de teat and seal off the borders and all trade while they attempt to consolidate power. The challenge to any one country would have the effect of chilling external relationships with the others; US trade would be directly affected during any individual crisis. Probability: Medium (3). Impact: Low (300K BD)

\section{Health Crisis}

Several new strains of disease are being identified in central Africa. The potential for a rare strain of Ebola virus to spread through central Africa is very real. One possible result would be a quarantine of all movement of people and goods out of the upper two-thirds of the continent. Probability: Low (2). Impact: High (1207K BD) 


\section{Vulnerability chart}

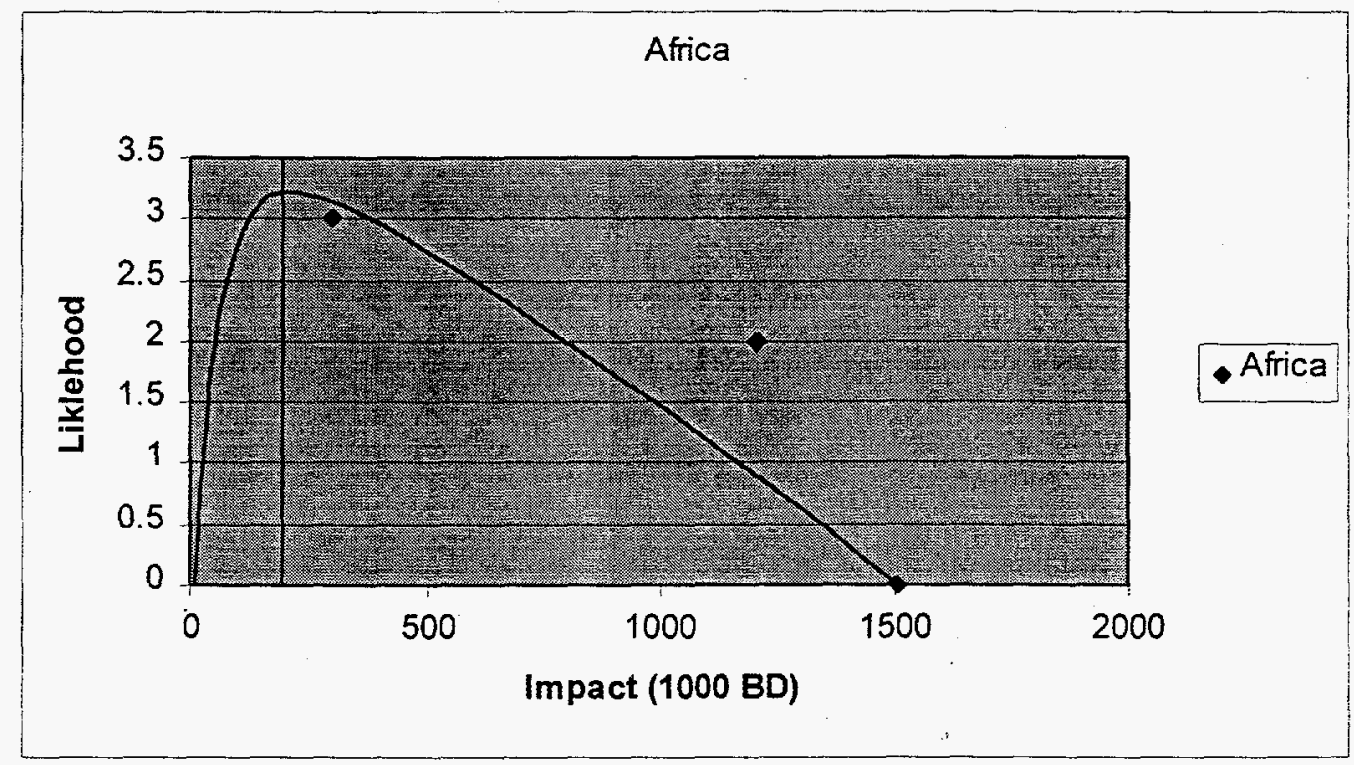

\section{Middle East \\ Countries}

Bahrain, Iran, Iraq, Kuwait, Oman, Qatar, Saudi Arabia, United Arab Emirates, Yemen

\section{Regional Issues}

\section{$\underline{\text { Bahrain }}$}

International disputes: Territorial dispute with Qatar over the Hawar Islands, maritime boundary with Qatar.

Internal political climate/stability: Traditional monarchy. Political parties are prohibited.

Several small, clandestine leftist and Islamic fundamentalist groups are active. A number of incidents occurred last year, most attributable to Islamic extremists who have sporadically fomented unrest and conducted attacks since the arrest of a popular Shi'a cleric in 1994. Economically, petroleum production and processing account for about $80 \%$ of export receipts, $60 \%$ of government revenues, and $30 \%$ of GDP. Economic conditions have fluctuated with the changing fortunes of oil since 1985. With its highly developed communication and transport facilities, Bahrain is home to numerous multinational firms with business in the Gulf. A large share of exports consists of petroleum products made from imported crude. Unemployment, especially among the young and the depletion of both oil and underground water resources are major longterm economic problems.

Current environmental issues: Desertification resulting from the degradation of limited arable land, periods of drought, and dust storms; coastal degradation (damage to coastlines, coral reefs, and sea vegetation) resulting from oil spills and other discharges from large tankers, oil refineries, and distribution stations; no natural fresh water resources so that groundwater and sea water are the only sources for all water needs. Natural hazards: periodic droughts, dust storms. 
International disputes: Iran and Iraq restored diplomatic relations in 1990 but are still trying to work out written agreements settling outstanding disputes from their eight-year war concerning border demarcation, prisoners-of-war, and freedom of navigation and sovereignty over the Shatt al-Arab waterway; Iran occupies two islands in the Persian Gulf claimed by the UAE: Lesser Tunb (called Tunb as Sughra in Arabic by UAE and Jazireh-ye Tonb-e Kuchek in Persian by Iran) and Greater Tunb (called Tunb al Kubra in Arabic by UAE and Jazireh-ye Tonb-e Bozorg in Persian by Iran); it jointly administers with the UAE an island in the Persian Gulf claimed by the UAE (called Abu Musa in Arabic by UAE and Jazireh-ye Abu Musa in Persian by Iran); in 1992 the dispute over Abu Musa and the Tunb islands became more acute when Iran unilaterally tried to control the entry of third country nationals into the UAE portion of Abu Musa island, Tehran subsequently backed off in the face of significant diplomatic support for the UAE in the region, but in 1994 it increased its military presence on the disputed islands; periodic disputes with Afghanistan over Helmand water rights; Caspian Sea boundaries are not yet determined; support to clients in Afghanistan. Iran is an identified state sponsor of terrorism as annually assessed and determined by the US Department of State.

Internal political climate/stability: The Islamic Republic established following the 1979 revolution and ouster of Shah Reza Pahlavi continues to tightly control activity within Iranian borders through fear and strict enforcement of the Saharia (or Islamic Law). The government is supported by a number of political pressure groups: groups to include Ansar-e Hizballah, Mojahedin of the Islamic Revolution, Muslim Students Following the Line of the Imam, and the Islamic Coalition Association. Opposition groups do exist to include the Liberation Movement of Iran and the Nation of Iran party; but armed political activism has been almost completely repressed by the government. Among the groups that have resorted to direct action in opposition are the Mojahedin-e Khalq Organization (MEK), People's Fedayeen, Kurdish Democratic Party of Iran; the Society for the Defense of Freedom. Iran's economy is a mixture of central planning, state ownership of oil and other large enterprises, village agriculture, and small-scale private trading and service ventures. Over the past several years, the government has introduced several measures to liberalize the economy and reduce government intervention, but most of these changes have moved slowly or have been reversed because of political opposition. Iran has faced increasingly severe financial difficulties since mid-1992 due to an import surge that began in 1989 and general financial mismanagement. At year-end 1993 the Iranian Government estimated that it owed foreign creditors about $\$ 30$ billion; an estimated $\$ 8$ billion of this debt was in arrears. At year-end 1994, Iran rescheduled $\$ 12$ billion in debt. Earnings from oil exports - which provide $85 \%$ of Iran's export revenues - are providing less relief to Iran than usual because of reduced oil prices. Iran's financial situation will remain tight in 1996 because the bulk of payments due under its rescheduling agreements in 1993-94 will be coming due. In addition to financial mismanagement and opposition to reform, Iran's economic woes can also be attributed to the monetary drain suffered as a result of their eight-year war with Iraq and recent expensive initiatives to re-arm and acquire of regional projection capability. Despite the Sharia's strict tenets relative to involvement in illicit drugs, Iran is also a producer of opium poppy for the domestic and international drug trade; produced 35-70 metric tons in 1993; net opiate importer but also a key transshipment point for Southwest Asian heroin to Europe. Throughout the country, Iran has over $5,900 \mathrm{~km}$ of crude oil pipeline.

Current environmental issues: Air pollution, especially in urban areas, from vehicle emissions, refinery operations, and industrial effluents; deforestation; overgrazing; desertification; oil pollution in the Persian Gulf; inadequate supplies of potable water.

Natural hazards: periodic droughts, floods, dust storms, sandstorms, and earthquakes along the Western border. 
International disputes: Iran and Iraq restored diplomatic relations in 1990 but are still trying to work out written agreements settling outstanding disputes from their eight-year war concerning border demarcation, prisoners-of-war, and freedom of navigation and sovereignty over the Shatt al Arab waterway; in November 1994, Iraq formally accepted the UN-demarcated border with Kuwait which had been spelled out in Security Council

Resolutions 687 (1991), 773 (1993), and 883 (1993); this formally ends earlier claims to Kuwait and to Bubiyan and Warbah islands; dispute over water development plans by Turkey for the Tigris and Euphrates Rivers. Iraq is an identified state sponsor of terrorism as annually assessed and determined by the US Department of State.

Internal political climate/stability: Saddam Hussein continues to have a firm grip on internal affairs in Iraq. Despite a post-Gulf War uprising in the north by Kurds and in the south by Shias, Iraq is still tightly ruled by the long-time dictator and a close circle of long-time associates that comprise the Revolutionary Council. The Ba'thist regime engages in extensive central planning and management of industrial production and foreign trade while leaving some small-scale industry and services and most agriculture to private enterprise. The economy has been dominated by the oil sector, which has traditionally provided about $95 \%$ of foreign exchange earnings. In the 1980 s, financial problems caused by massive expenditures in the eight-year war with Iran and damage to oil export facilities by Iran led the government to implement austerity measures and to borrow heavily and later reschedule foreign debt payments; Iraq suffered economic losses of at least $\$ 100$ billion from the war. After the end of hostilities in 1988, oil exports gradually increased with the construction of new pipelines and restoration of damaged facilities. Agricultural development remained hampered by labor shortages, salinization, and dislocations caused by previous land reform and collectivization programs. The industrial sector, although accorded high priority by the government, also was under financial constraints. Iraq's seizure of Kuwait in August 1990, subsequent international economic embargoes, and military action by an international coalition beginning in January 1991 drastically changed the economic picture. Industrial and transportation facilities, which suffered severe damage, have been partially restored. Oil exports remain at less than $5 \%$ of the previous level. Shortages of spare parts continue. Living standards deteriorated even further in 1994 and 1995; consumer prices have more than doubled in both 1994 and 1995. The UN-sponsored economic embargo has reduced exports and imports and has contributed to the sharp rise in prices. The Iraqi Government has been unwilling to abide by UN resolutions so that the economic embargo can be removed. The government's policies of supporting large military and internal security forces and of allocating resources to key supporters of the regime have exacerbated shortages. In brief, per capita output for 1994-95 is well below the 1989-90 level, but any estimate has a wide range of error. Within Iraqi territory, there is $4,350 \mathrm{~km}$ of crude oil pipeline.

Current environmental issues: Government water control projects have drained most of the inhabited marsh areas east of An Nasiriyah by drying up or diverting the feeder streams and rivers; a once sizable population of Shi'a Muslims, who have inhabited these areas for thousands of years, has been displaced; furthermore, the destruction of the natural habitat poses serious threats to the area's wildlife populations; inadequate supplies of potable water; development of Tigris-Euphrates Rivers system contingent upon agreements with upstream riparian Turkey; air and water pollution; soil degradation (salinization) and erosion; desertification. Natural hazards: dust storms, sandstorms, and floods.

\section{Kuwait}

International disputes: In November 1994, Iraq formally accepted the UN-demarcated border with Kuwait which had been spelled out in Security Council Resolutions 687 (1991), 773 (1993), and 
883 (1993); this formally ends earlier claims to Kuwait and to Bubiyan and Warbah islands; ownership of Qaruh and Umm al Maradim islands disputed by Saudi Arabia.

Internal political climate/stability: Another Gulf monarchy, Kuwait faces similar internal political pressures as seen in other Gulf emirates: principally, a challenge to legitimacy from Sunni and Shia activists. Personnel and US military and diplomatic facilities came under increasing threat in 1996. International terrorist financier Usama Bin Ladin publicly threatened US interests in the Gulf, including Kuwait, in September and again in December. Western establishments and US received numerous telephoned and faxed bomb threats during the year. Kuwaiti Hizballah, a Kuwaiti Shia organization that may have links to Iran, in 1996 allegedly assisted a Bahrain opposition group by smuggling weapons into Manama. Kuwaiti Hizballah may also have been engaged in activities directed against the US military presence in Kuwait. Other political or pressure groups in Kuwait include Bedouins, merchants, and secular leftists and nationalists. Economically, Kuwait is a small and relatively open economy with proved crude oil reserves of about 94 billion barrels - $10 \%$ of world reserves. Kuwait has rebuilt its war-ravaged petroleum sector; its crude oil production averaged 2.0 million barrels per day in 1994. The government continues to record large fiscal deficits. Petroleum accounts for nearly half of GDP, $90 \%$ of export revenues, and $70 \%$ of government income. Kuwait lacks water and has practically no arable land, thus preventing development of agriculture. With the exception of fish, it depends almost wholly on food imports. About $75 \%$ of potable water must be distilled or imported. Because of its high per capita income, comparable with Western European incomes, Kuwait provides its citizens with extensive health, educational, and retirement benefits. Per capita military expenditures are among the highest in the world. The economy improved moderately in 1994-95, with the growth in industry and finance. The World Bank has urged Kuwait to push ahead with privatization, including in the oil industry, but the government will move slowly on this front.

Current environmental issues: Limited natural fresh water resources, some of world's largest and most sophisticated desalination facilities provide much of the water; air and water pollution; desertification natural hazards: sudden cloudbursts are common from October to April, they bring inordinate amounts of rain which can damage roads and houses; sandstorms and dust storms occur throughout the year, but are most common between March and August.

\section{Oman}

International disputes: No defined boundary with most of UAE, but Administrative Line in far north.

Internal political climate/stability: There are no significant political challenges to the status quo in Oman. Economically, national performance is closely tied to the fortunes of the oil industry. Petroleum accounts for nearly $90 \%$ of export earnings, about $75 \%$ of government revenues, and roughly $40 \%$ of GDP. Oman has proved oil reserves of 4 billion barrels, equivalent to about 20 years' supply at the current rate of extraction. Agriculture is carried on at a subsistence level and the general population depends on imported food. The government is encouraging private investment, both domestic and foreign, as a prime force for further economic development. Internally, there is over $1,300 \mathrm{~km}$ of crude oil pipelines.

Current environmental issues: Rising soil salinity, beach pollution from oil spills, very limited

natural fresh water resources. Natural hazards: summer winds often raise large sandstorms and dust storms in interior, periodic droughts. 
International disputes: Territorial dispute with Bahrain over the Hawar Islands; maritime boundary with Bahrain; 1965 boundary with Saudi Arabia, renegotiated and revised in 1992, but not official depiction.

Internal political climate/stability: Qatar has had confirmed presence of international terrorists tied to Islamic extremism, but there are no significant challenges to the regime itself. Oil is the backbone of the economy and accounts for more than 30\% of GDP, roughly $75 \%$ of export earnings, and $70 \%$ of government revenues. Proven oil reserves of 3.3 billion barrels should ensure continued output at current levels for about 25 years. Oil has given Qatar a per capita GDP comparable to the leading West European industrial countries. Production and export of natural gas are becoming increasingly important.

Long-term goals feature the development of offshore petroleum and the diversification of the economy.

Current environmental issues: Limited natural fresh water resources are increasing dependence on large-scale desalination facilities. Natural hazards: haze, dust storms, sandstorms common.

\section{Saudi Arabia}

International disputes: Large section of boundary with Yemen not defined; location and status of boundary with UAE is not final, defacto boundary reflects 1974 agreement; Kuwaiti ownership of Qaruh and Umm al Maradim islands is disputed by Saudi Arabia; 1965 boundary with Qatar, renegotiated and revised in 1992, but not official depiction.

Internal political climate/stability: Although the House of Saud has instituted one of the most conservative societies in the Gulf region (embracing the Sharia, or Islamic Law), it is still the most beleaguered kingdom in the region relative to being challenged by both Sunni and Shia extremists. American presence on Saudi soil has been a source of profound agitation amongst the extremists and has resulted in two major terrorist attacks against US forces (the OPM/SANG and Ai Khobar Towers bornbings) over the past two years. In the iatier incident, which occurred in June 1996, several groups, both Shia and Sunni, purportedly claimed responsibility for the bombing, including: the "Brigades of the Martyr Abdallah al-Hudhaifi," "Hizballah al-Khalij," and the "Islamic Movement for Change." Saudi and US authorities are still investigating the incident. These movements are intent on replacing the monarchy with a theocracy operated in exile, the strongest of these headquartered in London (Islamic Movement for Change) and reports of support direct and indirect from Iranian and Syrian operatives have encircled the anti-US incidents. The Saudi kingdom remains strong with a well-to-do oil-based economy with positive government controls over major economic activities. About $40 \%$ of GDP is derived from the private sector. Economic (as well as political) ties with the US are especially strong. The petroleum sector accounts for roughly $75 \%$ of budget revenues, $35 \%$ of GDP, and $90 \%$ of export earnings. Saudi Arabia has the largest reserves of petroleum in the world (26\% of the proven total), ranks as the largest exporter of petroleum, and plays a leading role in OPEC. For the 1990 s, the government intends to bring its budget, which has been in deficit since 1983, back into balance, and to encourage private economic activity. Roughly, four million foreign workers play an important role in the Saudi economy, for example, in the oil and banking sectors. For over a decade, Saudi Arabia's domestic and international outlays have outstripped its income, and the government has cut its foreign assistance and is beginning to rein in domestic programs. For 1996, the country looks to its policies of maintaining moderate fiscal reforms, restraining public spending, and encouraging non-oil exports. Internally, the kingdom has over $6,400 \mathrm{~km}$ of crude oil pipelines. 
Current environmental issues: Desertification; depletion of underground water resources; the lack of perennial rivers or permanent water bodies has prompted the development of extensive seawater desalination facilities; coastal pollution from oil spills. Natural hazards: frequent sand and dust storms.

\section{United Arab Emirates}

International disputes: Location and status of boundary with Saudi Arabia is not final, defacto boundary reflects 1974 agreement; no defined boundary with most of Oman, but Administrative Line in far north; claims two islands in the Persian Gulf occupied by Iran: Lesser Túnb (called Tunb as Sughra in Arabic by UAE and Jazireh-ye Tonb-e Kuchek in Persian by Iran) and Greater Tunb (called Tunb al Kubra in Arabic by UAE and Jazireh-ye Tonb-e Bozorg in Persian by Iran); claims island in the Persian Gulf jointly administered with Iran (called Abu Musa in Arabic by UAE and Jazireh-ye Abu Musa in

Persian by (ran); in 1992, the dispute over Abu Musa and the Tunb islands became more acute when Iran unilaterally tried to control the entry of third country nationals into the UAE portion of Abu Musa island, Tehran subsequently backed off in the face of significant diplomatic support for the UAE in the region.

Internal political climate/stability: The UAE has an open economy with one of the world's highest incomes per capita and with a sizable annual trade surplus. Its wealth is based on oil and gas output (about $33 \%$ of GDP), and the fortunes of the economy fluctuate with the prices of those commodities. Since 1973, the UAE has undergone a profound transformation from an impoverished region of small desert principalities to a modern state with a high standard of living. At present levels of production, crude oil reserves should last for over 100 years. Although much stronger economically than most Gulf states, the UAE faces similar problems with weak international oil prices and the pressures for cuts in OPEC oil production quotas. The UAE Government is encouraging increased privatization within the economy. There are no significant challenges to the UAE political status quo and extremist activity is virtually non-existent, or transparent, at worst.

Current environmental issues: Lack of natural freshwater resources being overcome by desalination plants; desertification; beach pollution from oil spills. Natural hazards: frequent sand and dust storms.

\section{$\underline{\text { Yemen }}$}

International disputes: Large section of boundary with Saudi Arabia not defined; a dispute with Eritrea over sovereignty of the Hanish Islands in the southern Red Sea has been submitted to arbitration under the auspices of the International Court of Justice.

Internal political climate/stability: While there have been public reports of terrorism threats (particularly towards foreign visitors) within Yemen, the nation thus far has had little or no organized subversive activity since the reunification of the North and South governments. However, the country does experience violent acts against foreigners conducted by various tribal groups which inhabit the country. Whereas the northern city Sanaa is the political capital of a united Yemen, the southern city Aden, with its refinery and port facilities, is the economic and commercial capital. Future economic development depends heavily on Western-assisted development of the country's moderate oil resources. Former South Yemen's willingness to merge stemmed partly from the steady decline in Soviet economic support. The low level of domestic industry and agriculture has made northern Yemen dependent on imports for practically all of its essential needs. Once self-sufficient in food production, northern Yemen has become a major importer. 
Current environmental issues: Very limited fresh water resources; inadequate supplies of potable water; overgrazing; soil erosion; desertification natural hazards: sandstorms and dust storms in summer

\section{Scenarios and Examples}

Scenarios and potential disruptions of Persian Gulf oil have been the subject of many studies. Below are only three cursory examples, this is not an exhaustive or even representative collection.

\section{Strategic Position}

Abu Musa, an island in the Persian Gulf, is claimed by both Iran and the United Arab Emirates (UAE). The island is valued by these two countries for economic, security, and environmental reasons. One significant feature about this island is that it is potentially full of oil reserves. Currently, oil is being extracted from a field close to the shores of Abu Musa. The dispute over the island is unresolved and could ignite an international crisis at some point in the future. Probability: Medium (5). Impact: Medium (1200 BD)

\section{Blockade}

Iran, angered by increasingly pro-Western policies of Gulf Emirates and US influence in the region, initiates a naval blockade of the Strait of Hormuz. Probability: Low/Medium (4). Impact: Low (1641K BD)

\section{Renewal of Recent Hostilities}

Iraq re-invades Kuwait, moving through that country and proceeds to take control of Saudi Arabia's eastern oil fields. Any reengagement of warring parties in the Gulf region is the cause for supply disruption. The impact of the disruption is proportional to the individual country alliances and whether the US is a party to the conflict. The Gulf War is a classic example, Saudi Arabia being an ally of the US, completely made up the loss of Kuwaiti oil. If Saudi Arabia is either a non-combatant as in the past Iran/lraq wars, or is in fact opposed to US participation as has been developing recently in US/Iraq relationship, then the availability of swing supply may be gone. Probability: Low/Medium (4). Impact: Medium (1000K BD)

\section{Vulnerability chart}

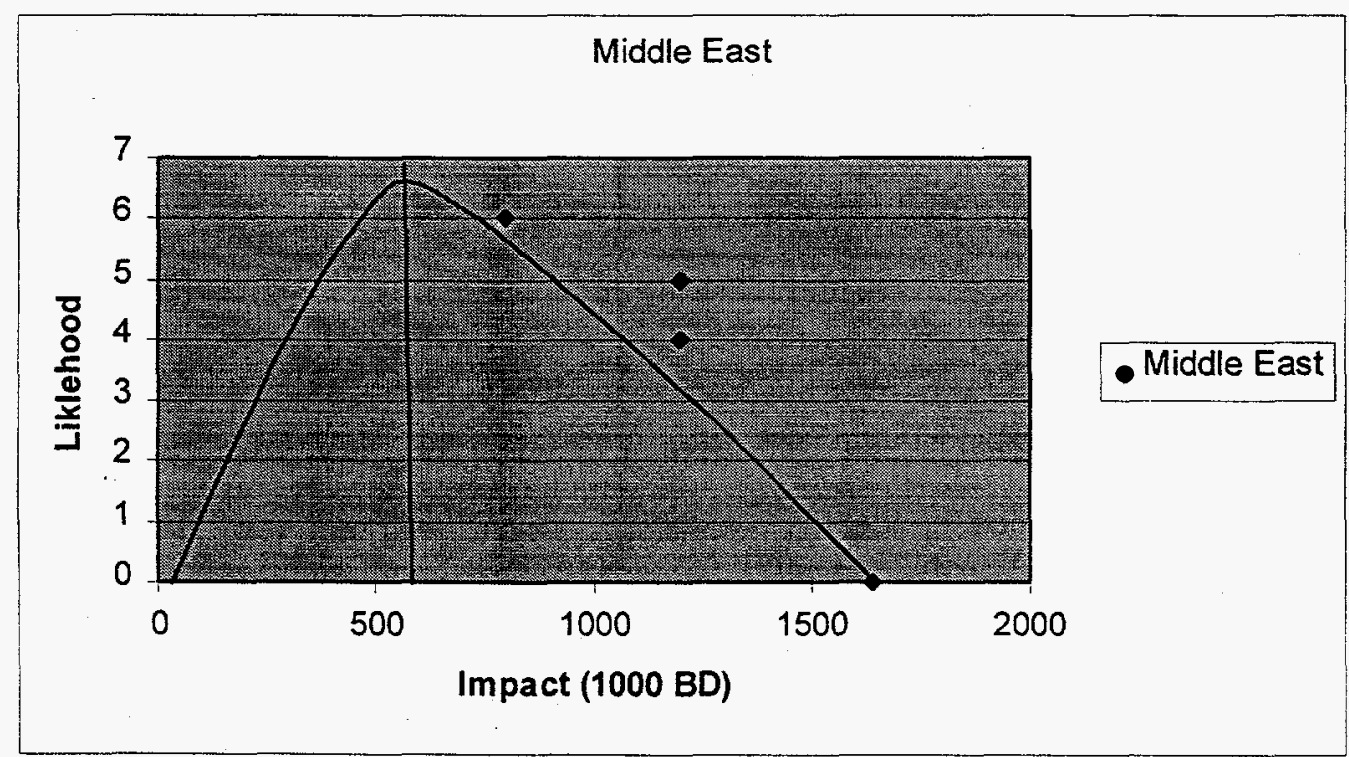




\section{Conclusions}

It is clear that the total vulnerability of US oil supply is spread across extensive regional sources. This does not decrease the total liability, but reduces the likelihood that all, or a large proportion of our imported crude oil supply can be terminated with one event. The combination of several interruptions leading to a cascading crisis is always possible, but not likely given the diverse and often competing threats across the world. Does this indicate that the US is secure? No, the very diversity that mitigates a crisis shortage also challenges energy policy and implementation of safeguards and protection measures. The chart below indicates the focus areas of concern and as expected, the Middle East provides the highest amount of vulnerability, but not disruption of the US total oil supply.

\begin{tabular}{|l|c|c|c|}
\hline Region & $\begin{array}{c}1996 \text { Imports to the } \\
\text { US } \\
\text { (thousands/ bb/s. } \\
\text { day) }\end{array}$ & $\begin{array}{c}\text { Likelihood of Supply } \\
\text { Disruption }\end{array}$ & $\begin{array}{c}\text { Potential } \\
\text { Vulnerability to } \\
\text { Disruption } \\
\text { (thousands/ bb/s. } \\
\text { day) }\end{array}$ \\
\hline Former Soviet Union & 24 & High & 8 \\
\hline Far East & 186 & Low & 20 \\
\hline Canada & 1416 & Low & 140 \\
\hline Mexico & 1239 & High & 123 \\
\hline South America & 2567 & Low & 250 \\
\hline Europe & 740 & High & 75 \\
\hline Africa & 1509 & Medium & 200 \\
\hline Middle East & 1641 & High & 600 \\
\hline
\end{tabular}

As can be seen from the above chart, the US is not vulnerable to a supply disruption from an individual source with magnitude even approaching the embargoes of the 1970s. It is vulnerable to several lesser disruptions, some of which could cascade and present difficult countermeasures and supply options. The additional interesting perspective is that the above analysis does not take into account the time duration of any given scenario.

It must also be recognized that the diversion of resources alone do not create crises or "price shock" vulnerabilities. This analysis does not take into account the time dimension of supply disruptions. Many of the high likelihood events are such that the disruption could be either repaired or re-established in a matter of days. Long-term disruptions would take on additional impact and seriousness. In fact, the concept of crisis must include the time duration of the disruption (Freund, et. al., 1995). The impact variable in the vulnerability graphs could be restructured to reflect the time value of the impact. For example, instead of measuring the impact in simple barrlls of oil, a complex factor such as barrels per day rmoved from the export stream could be used. This would focus vulnerability assessments on the replacement requirement.

In addition, the analysis does not take into account potential disruption occurring within the domestic arena. Terrorist actions, accidents and infrastructure decay is a focus of the President's Commission of Infrastructure Protection and are appropriately addressed in that context. 


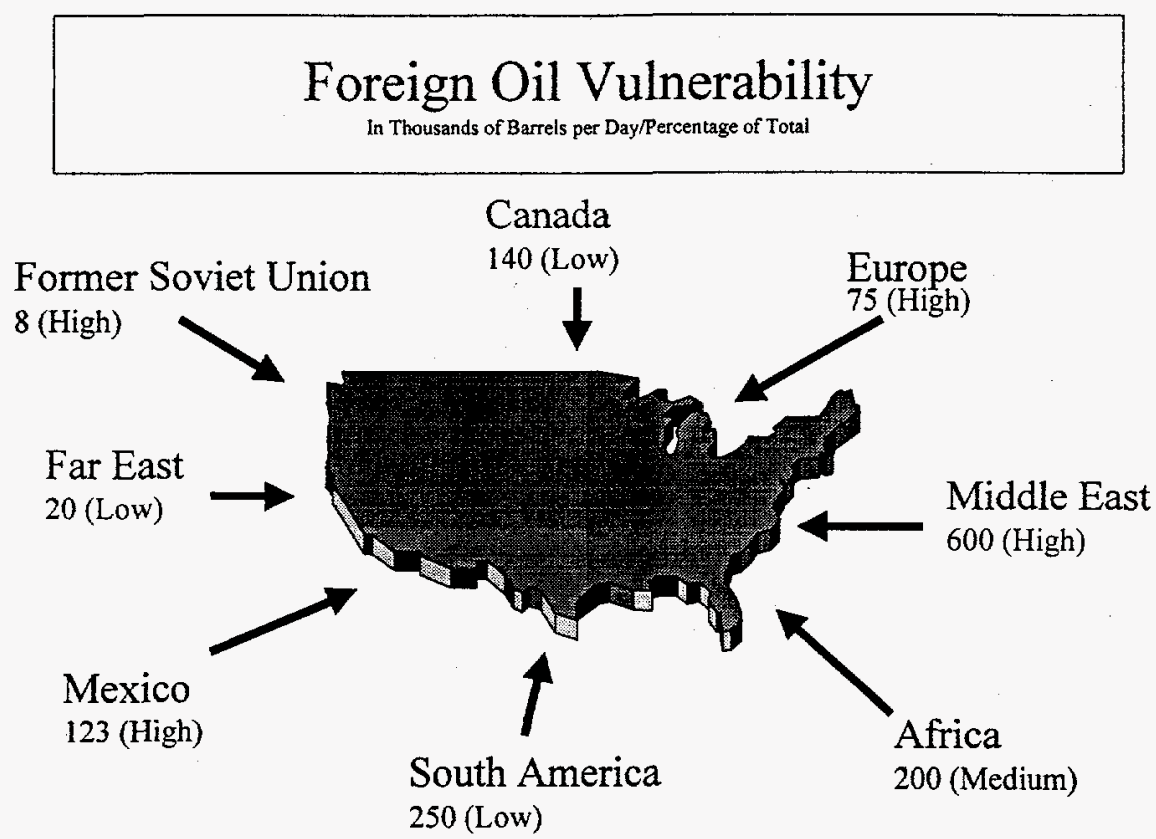

\section{Figure 6 Foreign Oil vulnerability}

The most important conclusion from this preliminary study is that the US is not vulnerable to having its entire import stream disrupted.

In fact, the largest imported oil stream is from South America, which yields radically different disruption concerns than the Persian Gulf. Conflict between Islamic fundamentalists, Israeli-Arab relationships and Iraqi intransigence are not germane to Latin American politics, culture or economic stresses. Drug cartel violence and government subornation, extreme left-wing insurgencies and the politics of poverty are the driving threats to stability and oil flow from this region. While the current threat to oil disruption appears to be low, there must be a focus on South America, as it is taking on the role of the chief exporting region to the US. The risk to US imports stems from political instability within each country and not the geopolitical stress of the 1970 's embargoes. While this reflects individual risks, the overall predictability of disruption may be much more difficult. It is important to see the effect of the Peruvian Embassy hostage crisis from the view of oil exports. No noticeable interruption was created by this event in Peru, but this is in part due to the small amount of Peruvian exports. Expansion of such rebel groups to major exporters such as Venezuela or Mexico would drastically alter this result.

Total vulnerability is an open question. While we have asserted rankings of high, medium and low, a robust analysis must be conducted to derive actionable conclusions. As a final note, the embargoes of the 1970s indicated that confusion in the market, coupled with widespread uncertainty about the future of supply led to panic buying, which further exacerbated shortages. In other words, energy disruptions can be significant and psychologically enduring despite being measurably small and transitory in volume.

Strategies to counter strategic vulnerabilities must be based on supply reality. It is impossible to prepare to replace the entire import amount, but strategic vulnerability assessment will provide logical, timely and balanced investment strategies to protect the US from supply disruptions. 


\section{References}

Adelman, M.A., 1989, Mideast Governments and the Oil price Prospect, Energy Journal, Vol. 10, No. 2, p. $15-24$

British Petroleum, 1997, BP Statistical Review of World Energy

Coy, P., and McWilliams, G., 1997, The New Economics of Oil, Business Week, November 3, p 141-148.

Department of State, 1997, Patterns of Global Terrorism, 1996, Department of state Publication 10433, April 1997, Washington, D.C.

Freund, M.T., Wise, J.A., Ulbarri, C.A., Shaw, B.R., and Roop, J.M, 1995, Identifying Future Courses for Crises, in Clawson, P.L., ed., Energy and National Security in the $21^{\text {st }}$ Century, National Defense University Press, Washington, D.C.

Greene, D.L., and Leiby, P.N., 1993, The Social Costs to the US of Monopolization of the World Oil Market, 1972-1991, ORNL-6744, Oak Ridge Tennessee, Oak Ridge National Laboratory

Greene, D.L., 1996, Twenty Years of Energy Policy, What should we have learned?, in Feldman, D.L., ed. The Energy Crisis, Unresolved Issues and Enduring Legacies, Johns Hopkins University Press, Baltimore

IEA, 1997, International Petroleum Statistics Report, Table 4.10, Net Oil Imports, 1986-1996.

Romm, J.J., and Curtis, D.B., 1996, "Mideast Oil Forever?", The Atlantic Monthly, April, 1996, P. 57-74.

Tippee, B., 1993, Where's the Shortage? A Nontechnical Guide to Petroleum Economics, PennWell Books, PennWell Publishing Co., Tulsa, Ok. 